\title{
Pharmacokinetics of fentanyl and its derivatives in children: a comprehensive review
}

\author{
Victoria C. Ziesenitz ${ }^{1,2}$, Janelle D. Vaughns ${ }^{3,4}$, Gilbert Koch ${ }^{1}$, Gerd Mikus ${ }^{5}$, and Johannes \\ N. van den Anker ${ }^{1,4,6}$
}

${ }^{1}$ Division of Pediatric Pharmacology \& Pharmacometrics, University of Basel Children's Hospital, Switzerland ${ }^{2}$ Department of Pediatric Cardiology, University Children's Hospital, Heidelberg, Germany ${ }^{3}$ Department of Anesthesia and Pain Medicine, Children's National Health System, Washington DC, USA 4Division of Clinical Pharmacology, Children's National Health System, Washington DC, USA ${ }^{5}$ Department of Clinical Pharmacology \& Pharmacoepidemiology, University Hospital Heidelberg, Germany ${ }^{6}$ Intensive Care and Department of Pediatric Surgery, Erasmus Medical Center-Sophia Children's Hospital, Rotterdam, the Netherlands

\section{Abstract}

Fentanyl and its derivatives sufentanil, alfentanil and remifentanil are potent opioids. A comprehensive review of the use of fentanyl and its derivatives in the pediatric population was performed using the National Library of Medicine PubMed. Studies were included if they contained original PK parameters or models using established routes of administration in patients younger than 18 years of age. Of 372 retrieved articles, 44 eligible pharmacokinetic studies contained data of 821 patients younger than 18 years of age, including more than 46 preterm infants, 64 fullterm neonates, 115 infants/toddlers, 188 children, and 28 adolescents. Underlying diagnoses included congenital heart and pulmonary disease and abdominal disorders. Routes of drug administration were intravenous, epidural, oral-transmucosal, intranasal, and transdermal. Despite extensive use in daily clinical practice, few studies have been performed. Preterm and term infants have lower clearance and protein binding. Pharmacokinetics was not altered by chronic renal or hepatic disease. Analyses of the pooled individual patients' data revealed that clearance maturation relating to body weight could be best described by the Hill function for sufentanil $\left(\mathrm{R}^{2}=0.71, \mathrm{~B}_{\max } 876 \mathrm{~mL} / \mathrm{min}, \mathrm{K}_{50} 16.3 \mathrm{~kg}\right)$ and alfentanil $\left(\mathrm{R}^{2}=0.70, \mathrm{~B}_{\max (\mathrm{fixed})} 420 \mathrm{~mL} / \mathrm{min}, \mathrm{K}_{50}\right.$ $28 \mathrm{~kg}$ ). The allometric exponent for estimation of clearance of sufentanil was 0.99 and 0.75 for alfentanil clearance. Maturation of remifentanil clearance was described by linear regression to bodyweight $\left(\mathrm{R}^{2}=0.69\right)$. The allometric exponent for estimation of remifentanil clearance was 0.76 . For fentanyl, linear regression showed only a weak correlation between clearance and bodyweight in preterm and term neonates $\left(\mathrm{R}^{2}=0.22\right)$ due to a lack of data in older age groups. A large

Corresponding author: Dr. V. C. Ziesenitz, MSc, Pediatric Pharmacology and Pharmacometrics, University of Basel Children's Hospital, Spitalstrasse 33, CH-4056 Basel, SWITZERLAND, Phone: +41 6170412 12, Fax: +41 6170412 13,

Ziesenitz.md@gmail.com.

Compliance with Ethical Standards

Conflict of Interest Statements

Victoria C. Ziesenitz, Janelle D. Vaughns, Gilbert Koch, Gerd Mikus and Johannes N. van den Anker declare no conflicts of interest that are directly relevant to the content of this review. 
heterogeneity regarding study design, clinical setting, drug administration, laboratory assays and PK estimation was observed between studies introducing bias into the analyses performed in this review. A limitation of this review is that PK data, based on different modes of administration, dosing schemes and parameter estimation methods, were combined.

\section{Keywords}

Fentanyl; sufentanil; alfentanil; remifentanil; pharmacokinetics; children; infants; adolescents; neonates; preterm infants; cardiopulmonary bypass; obesity; kidney disease; liver disease

\section{Introduction}

Fentanyl is commonly used within the field of anesthesia due to its high lipid solubility and potency. Based on the extensive use of fentanyl, its derivatives were developed and approved in the 1980s-90s [1, 2].

Fentanyl and like compounds exert their pharmacological action through interaction with the $\mu$-opioid receptor, see Table 1 for the relative potencies, physicochemical properties and pharmacokinetics (PK) of these substances in adults. Both fentanyl and sufentanil are drugs with a high extraction ratio while alfentanil has an intermediate extraction ratio [3, 4]. These compounds are metabolized by hepatic and intestinal CYP3A to pharmacologically inactive metabolites and show dose-linear PK [5-13].

Remifentanil is mainly metabolized through hydrolysis by unspecific plasma and tissue esterases to a metabolite lacking pharmacodynamic activity. Remifentanil shows a doseindependent clearance (CL), and has a much smaller volume of distribution (Vd) than fentanyl, resulting in a much shorter half-life $[14,15]$.

There are also distinct differences in their context-sensitive half-time, which is defined as the time required for the plasma drug concentration in the central compartment to decrease by $50 \%$ as a function of the duration of a continuous infusion but does not allow conclusions about the decrease in plasma concentration required for recovery from drug effect $[16,17]$. While fentanyl has a markedly prolonged context-sensitive half-time with increased infusion durations compared to alfentanil and sufentanil, remifentanil has a context-sensitive halftime independent of the infusion duration.

Intravenous fentanyl is currently used intraoperatively during general anesthesia [18]. Rapid onset fentanyl delivery systems like buccal or sublingual tablets, nasal spray, and lollipop are mainly used off-label in children. Transdermal fentanyl matrix patches are approved for opioid-tolerant children over 2 years of age. Sufentanil is also mainly used during general anesthesia but alfentanil and remifentanil can be utilized for analgo-sedation. Remifentanil is well suited for short or outpatient surgical procedures [18].

Their adverse effects are related to dose and effect-site concentrations and are mainly mediated by their $\mu$-opioid receptor agonism. Respiratory depression is the most relevant adverse effect. Other side effects include sedation, nausea, vomiting, constipation, pruritus, 
physical dependence, risk of addiction, bradycardia, and skeletal muscle rigidity, while hemodynamic responses rarely occur upon administration [18].

Despite the extensive use of fentanyl and its derivatives in children, only limited PK data in pediatric patients are available. This review considers the pharmacology of fentanyl and its derivatives sufentanil, alfentanil and remifentanil in infants, children, adolescents, and special pediatric sub-populations.

\section{Methods}

\subsection{Search strategy and selection criteria}

PubMed was searched systematically for articles published in English until February 28, 2017, to identify PK studies of fentanyl, sufentanil, alfentanil and remifentanil in pediatric patients (younger than 18 years). In the search string, each of the 4 compounds using Medical Subject Headings (MeSH), except remifentanil, was linked with AND to the following search terminologies: "children", "Pediatrics"[Mesh], "infant, premature" [Mesh], "infant, newborn"[Mesh], "infant"[Mesh], "child, preschool"[Mesh], "child" [Mesh], "adolescent" [Mesh]. To avoid missing data, an additional search was conducted: "compound" AND pharmacokinetics AND (infant OR infants OR newborn OR newborns OR child OR children OR childhood OR pediatric OR pediatrics OR paediatric OR paediatrics).

\subsection{Comprehensive review}

Abstracts of the selected articles were reviewed for eligibility. Studies were included if they contained relevant PK parameters or models, established routes of administration, and patients younger than 18 years of age. Identified studies and case reports were reviewed so that only those presenting original PK data were included. If individual children were considered in adult PK studies and individual pediatric data were given, these data were extracted and included. Studies reporting only drug concentrations in children were assessed in a descriptive manner.

In each publication, the following information was extracted and analyzed: type of study, the number of patients, the pediatric age group (according to ICH E11 guidelines [19]), the patient demographics, the used formulation, the route of administration, the number of PK samples taken from each patient, the sampling duration, the assay used for analysis, and relevant PK parameters (such as CL, half-life and Vd). Special populations were defined as patients with chronic kidney or liver disease, obesity, or on cardiopulmonary bypass (CPB) or extracorporeal membrane oxygenation (ECMO).

\subsection{Statistical analysis}

In order to assess the maturation of clearance, published individual clearance was related to bodyweight and, if relevant with respect to the literature, also to age by linear or non-linear regression models and allometric scaling. For non-linear regression, the Hill equation was applied [20,21]. This equation describes clearance saturation and allows sigmoidal behavior depending on the Hill coefficient $h$. Such a sigmoidal shape may be necessary for describing 
maturation processes of clearance in infancy and early childhood. Parameter $\mathrm{B}_{\max }$ stands for maximal clearance at saturation, and $\mathrm{K}_{50}$ corresponds to bodyweight that produces halfmaximal clearance. Additionally, data were log-log transformed to estimate the allometric exponent by the standard power law for clearance [22].

Statistical analyses were performed using GraphPad Prism version 7.00, GraphPad Software, La Jolla, California, USA. PK data were converted into comparable units for presentation in tables 2-5. Data are given as mean \pm standard deviation, or range, if not indicated differently.

\section{Results}

\subsection{Literature search}

The original search retrieved 8976 publications (fentanyl $n=5900$, sufentanil $n=590$, alfentanil $n=776$, remifentanil $n=1710$ ). After removal of duplicate entries and screening of the abstracts, 372 full text articles were downloaded. Five publications were found by scanning through the references of the articles.

Clinical studies were mostly prospective non-randomized open-label trials. Fentanyl and its derivatives were mainly administered intravenously (IV), but data on oral-transmucosal fentanyl citrate (OTFC), transdermal (TD) fentanyl, and epidural (EPI) fentanyl and sufentanil were available.

There were 44 publications focusing on PK (fentanyl $n=19$ [ 1 including alfentanil], sufentanil $n=8$, alfentanil $n=13$ [ 1 including fentanyl], remifentanil $n=5$ ), whereas drug concentrations were determined in another 30 studies (fentanyl $n=18$, sufentanil $n=8$, alfentanil $n=3$, remifentanil $n=1$ ).

The eligible PK studies presented data of 821 patients younger than 18 years of age, which included more than 46 preterm infants, 64 neonates, 115 infants/toddlers, 188 children and 28 adolescents. In 380 patients age was not specified. Congenital heart defects $(n=312)$, pulmonary/thoracic diseases $(n=91)$, neurological $(n=42)$ and abdominal $(n=38)$ disorders were the most common underlying diagnoses. Nineteen patients with chronic kidney disease were included, nine with liver disease, six obese, 282 on CPB, and 25 with kidney or liver transplants. Studies were mainly conducted during anesthesia or analgo-sedation.

Studies that measured plasma concentrations without PK assessments $(\mathrm{n}=27)$ included data of 671 pediatric patients, including 130 preterm neonates, 134 neonates, 64 infants/toddlers, 80 children and 9 adolescents.

\subsection{Statistical analysis}

Maturation of fentanyl clearance in preterm and term neonates showed a weak correlation to bodyweight $\left(\mathrm{R}^{2}=0.22\right.$, fig. 1$)$. Individual clearance data were not available for older children and therefore these results cannot be extrapolated from children to adults in linear manner also for theoretical considerations. 
Maturation of sufentanil and alfentanil clearance was assessed by fitting the Hill function $\left(\mathrm{R}^{2}=0.71\right.$ for sufentanil, Fig. 2 , and $\mathrm{R}^{2}=0.70$ for alfentanil, Fig. 3 , both weighted by $1 / \mathrm{y}^{2}$ ) to the dataset of all available clearance values including neonates for sufentanil and neonates and preterm infants for alfentanil.

For sufentanil, $B_{\max }$ as parameter for maximum clearance was estimated $876 \mathrm{~mL} / \mathrm{min}$ which lies in the documented range of adults $(10-15 \mathrm{~mL} / \mathrm{min} / \mathrm{kg}, 700-1050 \mathrm{~mL} / \mathrm{min}$ for $70 \mathrm{~kg}$ ). The bodyweight at which half-maximum clearance is reached $\left(\mathrm{K}_{50}\right)$ was estimated $16.3 \mathrm{~kg}$ which corresponds to the $50^{\text {th }}$ bodyweight percentile of a child aged $\sim 4-4.3$ years [23]. The allometric exponent for estimating sufentanil clearance was determined 0.99 for children older than one month (excluding neonates) weighing 3-70 kg (actual age 1 month to 18 years).

For alfentanil, $\mathrm{B}_{\max }$ was fixed to $420 \mathrm{~mL} / \mathrm{min}$ which corresponds to average adult clearance values (3-9 mL/min/kg, 210-630 mL/min for $70 \mathrm{~kg}$ ) and $\mathrm{K}_{50}$ was estimated $28.0 \mathrm{~kg}$ (corresponding to an age of $\sim 8.8$ years [23]). The allometric exponent for estimating alfentanil clearance was determined 0.75 for children older than one month (excluding preterm and term neonates) weighing $4.3-51 \mathrm{~kg}$ (actual age 3 months to 14 years). Thus, the Hill function reasonably well described maturation of clearance for both substances by a sigmoidal shape taking the maturation of clearance in early childhood into account.

Maturation of remifentanil clearance was described by linear regression $\left(R^{2}=0.69\right.$, Fig. 4). The Hill function was fitted as well but $\mathrm{B}_{\max }$ could not be determined probably due to few data in the saturation phase. Moreover, linear maturation of remifentanil clearance may be explained by the fact that remifentanil is metabolized by unspecific tissue and plasma esterases. Maturation of their metabolic capacity, however, has not yet been studied. The allometric exponent for remifentanil clearance was determined 0.76 for children (including neonates) weighing $2.5-96.8 \mathrm{~kg}$ (actual age 5 days to 17 years).

Results of linear or non-linear regression (solid line) together with allometric scaling (dashed line) are presented in the Figures. Reported parameter values in Figure legends are from linear or the Hill equation fit.

\section{Pharmacokinetics}

\subsection{Fentanyl}

4.1.1 Intravenous fentanyl-Few studies in neonates, infants and children have reported age-dependent differences (see table 2). Clearance and Vd in neonates and infants are higher than in adults and children, probably due to an increased hepatic blood flow (normalized to weight) and/or altered protein binding [24]. In a single neonatal case report protein binding was $63 \%$, clearly lower than in adults [25].

Fentanyl plasma concentrations after an intravenous bolus $(\sim 30 \mu \mathrm{g} / \mathrm{kg})$ were found to be lower in infants than in children, and in children lower than in adults [26]. These findings may result from a larger Vd or age-related differences in protein-binding. An increase in CL 
probably reflects maturation of CYP enzymes suggesting that the Michaelis-Menten constant is age-dependent $[27,28]$.

Neonates undergoing major surgery showed a highly variable disposition after a bolus of $25-50 \mu \mathrm{g} / \mathrm{kg}$ which was hemodynamically well tolerated [29]. No difference was found between doses and postnatal age. A rebound phenomenon was described in half of the patients due to tissue redistribution. Furthermore, half-life was prolonged in neonates with markedly increased intraabdominal pressure (1.5-3 times the population mean of 317 minutes) which may have compromised the blood flow in the splanchnic veins to the portal vein [30] impacting fentanyl metabolism [4, 31].

In neonates and infants during non-cardiac surgery, CL increased with age, with the most rapid increase at a postnatal age of 2 weeks, whereas $\mathrm{Vd}$ and half-life did not change after a bolus of $54.1 \pm 2.3 \mu \mathrm{g} / \mathrm{kg}[32]$.

After a fentanyl continuous infusion, half-life was prolonged and $\mathrm{Vd}$ at steady $\left(\mathrm{Vd}_{\mathrm{ss}}\right)$ state was increased due to a slow redistribution from peripheral compartments [33]. CL was highest in children 6 months to 6 years of age compared to younger or older children (8.2 $\mathrm{mL} / \mathrm{min} / \mathrm{kg}$ vs. $18.9 \mathrm{~mL} / \mathrm{min} / \mathrm{kg}$ vs. $8.0 \mathrm{~mL} / \mathrm{min} / \mathrm{kg}$ ) which was attributed to increased liver metabolism. There was considerable heterogeneity of patients regarding age and underlying disease.

The accuracy of a computerized assisted continuous-infusion using an adult PK dataset was evaluated in children between 2.7 and 11 years undergoing non-cardiac surgery [34]. The measured fentanyl concentrations mostly exceeded the predicted concentrations, so the finally derived pediatric 2-compartment model included age and bodyweight as covariates. However, this model is only applicable to infusion durations of up to 4 hours. This study also calculated a shorter context-sensitive half-time for children compared to adults after an infusion duration of up to 200 minutes, but the true effect-site concentrations in children versus adults and whether there are any differences among them, remain unknown.

An increase of plasma concentrations correlated with elevated $\mathrm{CO}_{2}$ throughout all age groups. Therefore, infants were not more prone to ventilator depression than children or adults $[35,36]$.

An opportunistic sampling strategy was applied in children after cardiac surgery which proved that this technique is applicable to clinical routine since PK parameters were comparable to prior formal studies [37].

In summary, fentanyl was studied in children of all ages, but the majority of data was generated in the newborn period. Age-related changes in PK were observed but data are scarce considering most studies were conducted when high doses of fentanyl were used.

4.1.1.1 Preterm neonates: Unfortunately, PK sampling in neonates is usually limited. Therefore, estimation of half-life may become inaccurate if extrapolation of data is not carefully performed [38]. Postnatal and postmenstrual age both affect PK, since preterm infants showed slightly higher CL than neonates born at term (26.2 vs. $21.1 \mathrm{ml} / \mathrm{kg} / \mathrm{min})$, but 
the preterms were older regarding postnatal age (36.7 vs. 13.3 days) [29, 32]. Other studies reported a significant correlation between postnatal age $\left(\mathrm{R}^{2}=0.64\right)$ or $\mathrm{GA}\left(\mathrm{r}=0.46, \mathrm{R}^{2}=0.21\right)$ and birth weight ( $r=0.48, \mathrm{R}^{2}=0.23$ ) with CL $[39,40]$, but for the last two it was actually as weak as in the pooled analysis of this review (weight $R^{2}=0.22$, Fig. $1, G A R^{2}=0.23$ ), and for postnatal age not even significant.

Difficulties in estimation of half-life were seen in preterm infants (GA 31.8 \pm 4.7 weeks) in whom fentanyl plasma concentrations after a bolus $(30 \mu \mathrm{g} / \mathrm{kg})$ were almost stable from $0.5-$ 2 hours resulting in an elimination half-life of 6 to 32 hours [41]. There were no adverse hemodynamic changes towards fentanyl reported.

Although body fat mass is much lower and total body water is much higher in premature infants than in newborns or older infants [42], Vd was increased in comparison to newborns and older children and half-life was prolonged [29, 32, 33]. This may be attributed to lower plasma protein concentrations (albumin and a-1-acid-glycoprotein) in preterms and thus a higher free fraction of the drug [42].

Fentanyl showed dose-linear PK during continuous infusion in preterm neonates. Clearance was slightly lower in preterms $<34$ weeks GA than $\geq 34$ weeks GA, but with high interindividual and inter-day variability. Circulatory parameters were stable and fentanyl provided effective analgesia. Meconium excretion occurred later and plasma bilirubin was higher in the fentanyl group, most probably due to a longer gastrointestinal transit time.

Premature neonates showed no signs of cardiorespiratory compromise during continuous infusions [39, 43] but baroreflex control of heart rate was depressed after fentanyl administration. Thus, the ability of neonates to adapt to a decrease in blood pressure by increasing heart rate and thus cardiac output is disturbed [44].

In preterm infants with a $\mathrm{GA}<33$ weeks, a fentanyl bolus was more suitable for treating acute pain episodes in ventilated infants than a continuous infusion which led to increased side effects such as longer ventilation duration and reduced gastrointestinal motility [45]. Chest wall rigidity and laryngospasm have been observed even after low bolus doses of 3-5 $\mu \mathrm{g} / \mathrm{kg}$ in preterm and term infants [46].

Plasma binding of fentanyl in vitro in umbilical cord blood was $77 \%$ in preterm infants compared to $70 \%$ in neonates [47], but fentanyl concentrations $(125 \mathrm{ng} / \mathrm{mL})$ considerably exceeding therapeutic ranges (1-20 ng/mL, factor 6.25-125) were used. Alpha-1-acidglycoprotein was lower in preterm compared to term neonates, while albumin concentrations were similar. Fentanyl already caused an analgesic effect and respiratory depression at plasma concentrations of $1-3 \mathrm{ng} / \mathrm{mL}$ [48].

Samples from the umbilical cord in preterm and term infants undergoing ex utero intrapartum therapy due to airway and lung pathologies [49] proved analgesic fentanyl concentrations in all patients.

In summary, fentanyl, which currently is the most frequently used opioid analgesic in the neonatal intensive care unit, shows highly variable kinetics in preterm neonates after bolus 
dosing or continuous infusion (17-fold variation in clearance between individual patients with a range of 3.4 to $58.7 \mathrm{~mL} / \mathrm{min} / \mathrm{kg}$, Fig. 1)[50]. Withdrawal symptoms may occur after several days of continuous infusion. Fentanyl may cause relevant side effects at low doses, therefore studies are needed evaluating the PK-PD relationship of fentanyl in this vulnerable group of patients.

4.1.1.2 Kidney disease: Chronic kidney disease (CKD) or end-stage renal failure not only impacts renal elimination, but also non-renal CL of drugs [51]. Fentanyl does not undergo renal metabolism, but is excreted via the kidneys into the urine, predominantly as inactive metabolites [52-54]. Therefore absent kidney function should not significantly alter PK.

Two children with renal disease receiving fentanyl for surgery are described in a case series [55]. While PK did not differ during corrective cardiac surgery from other studies in the first patient, the second patient showed an extreme prolongation of half-life [56]. A study described above included two children with renal failure, but their fentanyl CL was comparable with other patients [33].

4.1.1.3 Cardiopulmonary bypass: Extracorporeal circulation (CPB or ECMO), leads to changes in PK, such as hemodilution due to circuit priming, an increased Vd due to addition of a large exogenous volume, a prolonged half-life, changes in plasma protein concentrations and a reduction in renal or hepatic function [57]. ECMO may have an even greater impact on PK than CPB due to a longer treatment duration, such as days to weeks [57].

Hypothermia during $\mathrm{CPB}$ impacts drug metabolism, as hepatic clearance decreases due to reduced liver blood flow and activity of drug-metabolizing enzymes [58]. Renal clearance decreases during extracorporeal circulation due to reduced glomerular filtration caused by impaired renal perfusion [59].

Drug sequestration and adhesion to the surface of circuit components cause alterations in drug disposition. Drug adsorption correlates with the lipophilicity of the drug, but adsorption also depends on the equipment used for ECMO [60]. In a series of studies, initiation of CPB lead to a $60-89 \%$ decrease of plasma concentrations, attributed to a rapid sequestration of fentanyl within the bypass circulation due to binding of fentanyl to components of the CPB system [56, 61]. Therefore, fentanyl was not recommended as the primary analgesic agent in patients on ECMO, since the lipophilic drug is highly adsorbed to ECMO circuit components and shows a decreased CL during hypothermia [62].

After the initial decrease, fentanyl plasma concentrations remained stable during the further course of CPB [55, 64], also during hypothermia [65]. Even priming of the pump with 20 $\mathrm{ng} / \mathrm{mL}$ fentanyl did not prevent this effect [66]. When more modern equipment was used, only minimal variability in plasma concentrations was observed before, during and after hypothermic CPB using a low-volume circuit and constant fentanyl infusion [63]. A significant reduction of serum albumin concentrations was observed due to CPB which was likely to be caused by hemodilution, propably not affecting the unbound fraction of fentanyl [66]. Also, the degree of hemodynamic impairment may be a major determinant of fentanyl 
distribution [67]. During modified ultrafiltration after CPB, at least stable [68] or increasing fentanyl plasma concentrations were reported [69].

In the studies conducted early after its introduction, higher doses of fentanyl per kg bodyweight ( $>10$ and up to $50 \mu \mathrm{g} / \mathrm{kg}$ ) were used since there were only limited other anesthetic agents. Fentanyl suppressed the stress response to surgery and still provided hemodynamic stability as it lacks myocardial depressant effects [70,71]. No correlation was found between fentanyl concentrations, bispectral index, and hemodynamic, metabolic or hormonal markers of depth of anesthesia [72].

During ECMO, neonates rapidly developed tolerance towards the sedating effect of fentanyl, resulting in a progressive escalation of fentanyl infusion rates and rising steady-state plasma concentrations increasing the risk of neonatal abstinence syndrome [38, 73, 74]. CL may be impaired in seriously ill patients during ECMO which may be due to decreased liver blood flow during compromised circulatory function [75].

4.1.1.4 Obesity: Obesity has become a challenge in pediatric anesthesia since the rates of pediatric overweight and obesity are rising [76,77]. Pediatric obesity is defined by a BMI > 95 ${ }^{\text {th }}$ percentile [78].

A pilot study in morbidly obese adolescents (mean BMI $49.6 \mathrm{~kg} / \mathrm{m}^{2}$ ) showed enhanced CL while Vd was comparable to that in lean adults after dosing based on IBW [79]. Although the results suggest that a loading dose of fentanyl may be based on TBW followed by maintenance doses based on IBW and/or LBW [80, 81], obese patients are more at risk for respiratory side effects of opioids [82-86].

4.1.2 Epidural fentanyl—Epidural administration of fentanyl resulted in peak plasma concentrations 30 minutes after the loading dose, but a substantial variability during continuous epidural infusion supplemented by patient-controlled bolus doses in children aged 6-11 years was observed [87]. In children of comparable age, half-life was not only longer in infants than children (median 15.9 vs. $7.96 \mathrm{~h}$ ) but longer than observed after IV administration [88]. In addition, an increase in plasma concentrations was noted after discontinuation of the infusion attributed to redistribution. Consequently, continued clinical monitoring is required during neuraxial analgesia.

4.1.3 Transmucosal fentanyl-After comparable doses, maximal fentanyl concentrations were lower in children after administration of oral transmucosal fentanyl citrate (OTFC), whereas the time to achieve them was longer in adults [89].

OTFC given as premedication to children aged 2 to 10 years resulted in a bioavailability of $33 \%$ compared to $50 \%$ in adults $[90,91]$. The efficacy of $10-15 \mu \mathrm{g} / \mathrm{kg}$ OTFC was comparable to $2 \mu \mathrm{g} / \mathrm{kg}$ intravenous fentanyl. Bioavailability was also low (36\%) in another study in patients of the same age, but PK was similar [92]. $\mathrm{T}_{\max }$ was highly variable (14 to $121 \mathrm{~min}$ ), most probably due to variability in gastrointestinal absorption, resulting in difficulties in timing of administration. When the intravenous solution was given orally (10$15 \mu \mathrm{g} / \mathrm{kg}$, max. $400 \mu \mathrm{g}$ ), PK was comparable to the previous 2 studies, but the apparent oral 
$\mathrm{Vd}$ was significantly larger and $\mathrm{T}_{\max }$ was much longer (the latter could be due to methodological difficulties [93]). Side effects of OTFC for preoperative sedation were nausea and vomiting, pruritus, respiratory depression and chest-wall rigidity. OTFC should be carefully used in children less than 6 years [94-97]. Intranasal fentanyl (dosed 1-2 $\mu \mathrm{g} / \mathrm{kg}$ ) has been effectively used in premedication, emergency analgesia and palliative care [98$102]$.

4.1.4 Transdermal fentanyl-Transdermal application is a convenient non-invasive route of administration. In children who were treated with transdermal fentanyl for postoperative pain control (dose $25 \mu \mathrm{g} / \mathrm{h}, 1.72 \mu \mathrm{g} / \mathrm{h} / \mathrm{kg}$ ), maximum plasma concentrations were negatively correlated with the patients' age, but not with bodyweight [103]. Respiratory depression was not observed. In another study, time to reach $\mathrm{C}_{\max }$ ranged from 18-66 hours in children after patch application $(25 \mu \mathrm{g} / \mathrm{h})$ [104]. Transdermal PK is similar to those in adults [105-107].

\subsection{Sufentanil}

4.2.1 Intravenous sufentanil-Sufentanil PK (table 3) showed age-related differences in children undergoing cardiac surgery after a single dose $(10-15 \mu \mathrm{g} / \mathrm{kg})$ [108]. CL was lowest in neonates compared to infants, children and adolescents. Half-life was longest and $\mathrm{Vd}_{\mathrm{ss}}$ was largest in newborns compared to the older age groups. Neonates needed additional anesthetics at significantly higher plasma concentrations compared to older children to suppress the hemodynamic response to painful stimuli, but younger infants did not receive premedication before surgery [38]. CL and Vd increased while half-life decreased slightly in a case series of neonates who were studied twice during the first 4 weeks of life [109].

In children aged 2-8 years undergoing surgery, $\mathrm{CL}$ was twice as rapid as in adults after a bolus dose $(1-3 \mu \mathrm{g} / \mathrm{kg})$ [110]. Vd was larger than in adults when normalized to bodyweight, but similar to that in adults when normalized to body surface area. Sufentanil plasma binding was lowest in newborns (80.5\%) compared to infants (88.5\%), children (91.9\%) and adults $(92.2 \%)$ while sufentanil is usually highly protein-bound $(92.5 \%)$ in adults $[111,112]$. Sufentanil was $79.3 \%$ plasma-protein bound in neonates compared to $90.7 \%$ in their mothers, while a 1-acid-glycoprotein concentrations in the neonates were $50 \%$ of the adult values [113].

Two studies investigating PK included 1 pediatric patient, respectively [114, 115]. Long half-lives were reported in patients receiving a continuous infusion $[115,116]$. Allometric scaling for dose-adaptation in pediatric patients was suggested [116].

Dose-linearity of 250-1500 $\mu \mathrm{g}$ sufentanil was shown in adolescents and adults aged 14 to 68 years. Sufentanil metabolic CL was almost identical to hepatic blood flow [12].

In summary, sufentanil PK show weight-related increases in CL and $\mathrm{Vd}$ while most maturation processes occur around 4 years of age (Fig. 2) and during the first weeks of life [109]. Normalized to bodyweight, CL and Vd in infants and children older than 1 month of age reached twice the adult values $[3,12,110]$. The allometric exponent of 0.99 best describing maturation of clearance differs from previous practice suggesting an allometric 
exponent of 0.75 in pediatric patients [117]. A linear model, however, would overestimate the clearance of sufentanil in children exceeding 35-40 kg of bodyweight (Fig. 1).

4.2.1.1 Preterm neonates: Sufentanil has been used in preterm neonates but no PK was assessed [118].

4.2.1.2 Kidney disease: Renal failure had no significant effect on PK in children and adolescents undergoing general anesthesia before kidney transplantation [119]. Children with chronic renal failure, however, showed a higher individual variability in CL and halflife.

4.2.1.3 Cardiopulmonary bypass: Sufentanil Vd was significantly smaller in infants under 10 months of age, while half-life and CL were similar after a single intravenous dose (15 $\mu \mathrm{g} / \mathrm{kg}$ ) in infants and children undergoing CPB [120]. Surface-cooling led to an increase in the $\mathrm{Vd}$ and almost twice the half-life value, while $\mathrm{CL}$ was similar to the uncooled groups. Hemodynamic responses could be observed upon sufentanil administration.

Sufentanil plasma concentrations were clearly overestimated by a computerized assisted continuous-infusion, which could be due to a rapid decline of plasma concentrations after initiation of CPB [121].

4.2.2 Epidural sufentanil-Plasma concentrations after epidural administration reach a $\mathrm{C}_{\max } 20$ minutes after the loading dose [87]. Considerable redistribution was observed and a slow elimination after continuous infusion with a median half-life of $19.6 \mathrm{~h}$ in children aged 3-36 months comparable to an earlier study [122, 123].

4.2.3 Transmucosal sufentanil-Intranasal application was described as a safe and effective method for premedication in children [124, 125]. Higher doses, however, led to a higher incidence of postoperative nausea and vomiting. Compared to midazolam, the latter showed advantages regarding respiratory depression, postoperative nausea and vomiting and time to discharge [126-128]. Plasma concentrations after intranasal application (single dose $2 \mu \mathrm{g} / \mathrm{kg}$ ) showed a $C_{\max } 15-30$ minutes after administration [129]. In another study, $C_{\max }$ occurred 13.8 minutes after application and bioavailability was $24.6 \%$ [130].

\subsection{Alfentanil}

4.3.1 Intravenous alfentanil-Alfentanil (table 4) CL in children aged 5.4 \pm 1.1 years was similar to adults, but half-life was significantly less and Vd significantly smaller $(0.16 \pm 0.11$ L/kg vs. $0.46 \pm 0.16 \mathrm{~L} / \mathrm{kg}$ ) in children [131]. Protein binding was comparable (91.8-94.4\%) in both groups. Similar protein binding (free fraction 11.5 $\pm 0.9 \%$ ) was reported in children aged 10 months to 6.5 years [132]. Half-life was shorter and CL was higher compared to adults $(11.1 \pm 3.9$ vs. $5.9 \pm 1.6 \mathrm{~mL} / \mathrm{min} / \mathrm{kg}$ ). In contrast, plasma protein binding in neonates was clearly lower than in their mothers $(67.2 \%$ vs. $88.2 \%)$ [113].

An increase in dose from $50 \mu \mathrm{g} / \mathrm{kg}$ to $120 \mu \mathrm{g} / \mathrm{kg}$ resulted in a proportional increase in exposure in children between 3 months and 14 years undergoing surgery [13] suggesting 
dose-independent PK. Half-life, CL and Vd were similar in infants compared to older children.

In contrast, a non-linear increase in plasma concentrations was observed when comparing different doses, $(85 \mu \mathrm{g} / \mathrm{kg}$ bolus with $65 \mu \mathrm{g} / \mathrm{kg} / \mathrm{h}$ infusion, and $65 \mu \mathrm{g} / \mathrm{kg}$ bolus with a 50 $\mu \mathrm{g} / \mathrm{kg} / \mathrm{h}$ infusion) in children aged 3-12 years [133]. Approximately doubled plasma concentrations were observed after the higher dose $(279 \pm 78 \mathrm{ng} / \mathrm{mL}$ vs. $135 \pm 30 \mathrm{ng} / \mathrm{mL})$ suggesting dose-dependent PK [133]. Dose-linearity was assessed in neonates but the results were inconclusive since a limited number of plasma samples was drawn [134].

Overall, PK seems to be dose-independent, since there was no evidence for saturation of metabolism and drug accumulation when PK parameters after dosing of 20 to $200 \mu \mathrm{g} / \mathrm{kg}$ were compared $[13,135]$.

Fentanyl $(2 \mu \mathrm{g} / \mathrm{kg} / \mathrm{h})$ had a much longer half-life (15.9 vs. $4.9 \mathrm{~h})$ and a much larger $\mathrm{Vd}$ at steady state (17.2 vs. $1.3 \mathrm{~L} / \mathrm{kg}$ ) given as continuous infusion when compared to alfentanil $(20 \mu \mathrm{g} / \mathrm{kg} / \mathrm{h})$ [136]. Healthy children had similar PK profiles than the study discussed above $[135,137]$.

Alfentanil PK was used to predict CYP3A-mediated drug clearance by physiologically based PK modeling. Allometric scaling failed to predict alfentanil CL in neonates in one study [138], but another study reported no age-dependent bias in a model for term neonates up to the age of 18 years. However, in premature neonates, $\mathrm{Vd}$ and half-life were underestimated [139]. A new physiologically based PK model [140] showed improved predictions regarding the ontogeny function for CYP3A when compared to previously reported models [141]. In the pooled analysis of this review, the allometric exponent describing maturation of clearance was 0.75 for children between 3 months and 14 years of age.

In summary, alfentanil $\mathrm{CL}$ in healthy infants and children normalized to bodyweight was comparable to adult values and occasionally exceeded them. CL in neonates and preterm neonates was significantly less, while half-life is prolonged. Most maturation processes of CL occur around the age of 8.8 years, but there were limited PK data in children with a bodyweight over $25 \mathrm{~kg}$ (Fig. 3).

4.3.1.1 Preterm neonates: Plasma protein binding in vitro in umbilical cord blood samples was $65 \%$ compared to $79 \%$ in term neonates which correlated with gestational age and concentration of a-1-acid-glycoprotein, lower than in older children $(92.4-94.4 \%)$ [47, 131].

In premature neonates with a gestational age of $29.5 \pm 3.3$ weeks, $C L$ was lower $(2.2 \pm 2.4$ vs. $5.6 \pm 2.4 \mathrm{~mL} / \mathrm{kg} / \mathrm{min})$, Vd was larger $(1.0 \pm 0.39$ vs. $0.48 \pm 0.19 \mathrm{~L} / \mathrm{kg})$ and half-life was much longer after a bolus $(25 \mu \mathrm{g} / \mathrm{kg})$ compared to older infants and children (age 5.0 $\pm 2.8 \mathrm{y})$ [135]. The differences in body composition in preterm infants, such as a higher body water content, less fat and muscle mass as well as reduced protein binding might explain these differences.

A high variability of PK was observed after a bolus dose $(20 \mu \mathrm{g} / \mathrm{kg})$ in another preterm cohort (GA 25-36 weeks), but CL was lower and half-life was longer, whereas the Vd was 
similar in older children [142]. No association was observed between weight, gestational age, age or gender. Alfentanil did not seem to accumulate in preterm infants even if given as $5 \mu \mathrm{g} / \mathrm{kg} / \mathrm{h}$ infusion. Although the total infusion duration was not reported, it seemed to be longer than 48 hours.

Term and preterm neonates with a gestational age of 26-35 weeks who received a bolus dose $(25 \mu \mathrm{g} / \mathrm{kg}$ ) during their first 3 days of life showed no alterations in hemodynamics. PK showed a considerable variability and did not differ between preterm and term neonates, but CL was lower and half-life was longer when compared to older children [143].

When low-dose alfentanil (mean $11.7 \mu \mathrm{g} / \mathrm{kg}$ ) was administered to newborn and preterm infants during their first 3 days of life, $65 \%$ of patients showed symptoms of skeletal muscle rigidity which disappeared spontaneously after 10 minutes. Pharmacokinetics was not different between both groups [144].

In summary, half-life was longer and CL lower in newborns and preterm neonates compared to children, while there were conflicting results for $\mathrm{Vd}[135,143]$. Reported chest wall rigidity remains a safety concern in this age group [144]. Therefore, more studies are needed to investigate the relationship of PK and PD [38].

4.3.1.2 Liver disease: Liver disease may have a variable effect on PK due to altered intrinsic enzyme activity, hepatic blood flow, hepatocellular function and protein binding. Existing data do not allow correlations between distinct hepatic diseases and specific PK alterations [145]. Hepatic diseases with preserved hepatic blood flow may not affect the PK of highextraction ratio drugs. In contrast, the hepatic clearance of low extraction-ratio drugs depends mainly on enzymatic activity [146].

Pharmacokinetics seemed to be unaffected by cholestatic liver disease in children aged 0.7515 years [137]. Liver transplant patients were studied before the anhepatic phase and 8 to 12 hours after reperfusion. A significant decrease in CL was found after liver transplant (7.0 \pm 3.8 vs. $11.2 \pm 2.7 \mathrm{ml} / \mathrm{kg} / \mathrm{min}$ ), while the increases in apparent $\mathrm{Vd}$ and half-life were not significant. Dose reduction of alfentanil is recommended during liver transplantation [147].

4.3.1.3 Kidney disease: No difference in PK compared to healthy children could be found in children with end-stage renal disease dependent on peritoneal or hemodialysis who received alfentanil during anesthesia for kidney transplantation [11].

4.3.1.4 Cardiopulmonary bypass: The initial Vd was smaller and the dose-normalized AUC was significantly greater before (bolus $200 \mu \mathrm{g} / \mathrm{kg}$ ) than after (bolus $80 \mu \mathrm{g} / \mathrm{kg}$ ) CPB in infants and children [148]. Alfentanil administration led to a significant hemodynamic response in both patient and dose groups comparable to previous data [36, 149]. A higher recovery of alfentanil (80\%) compared to fentanyl (29\%) after 60 minutes circulation time through CPB in vitro was observed [61]. 


\subsection{Remifentanil}

4.4.1 Intravenous remifentanil-PK (table 5) was studied in children of different age groups during surgery [150]. Half-life was similarly short across all age groups and comparable to adult values, while Vd was highest and CL was fastest in infants under 2 months of age compared to older infants, children and adolescents, normalized to bodyweight $[150,151]$. About $17 \%$ of patients developed arterial hypotension after a bolus dose of $5 \mu \mathrm{g} / \mathrm{kg}$. Another study described remifentanil PK during postoperative sedation by a 2-compartment allometric model [152]. Regarding the hypotensive effect in infants, it was estimated that a plasma concentration of $14 \mathrm{ng} / \mathrm{mL}$ would cause a $30 \%$ decrease in mean arterial blood pressure [153]. When compared to halothane, remifentanil did not cause newly-onset postoperative respiratory depression [154]. But due to the short recovery time from anesthesia, supplemental analgesia has to be administered for postoperative pain management.

Although remifentanil is not recommended during the first year of life, it was shown to have a favorable safety and efficacy profile in neonates $[155,156]$. Remifentanil is currently used for sedation of neonates during mechanical ventilation [157, 158]. Despite higher doserequirements in newborns and young infants, they were more tolerant towards the respiratory depressant effect [159]. Recovery times were short even in neonates [160].

In summary, remifentanil has predictable PK in children aged 5 days to 17 years and clearance showed bodyweight-linear maturation. When assessed by an allometric function, however, the allometric exponent was 0.76 (Fig. 4), and both models described maturation of remifentanil clearance equally well $\left(\mathrm{R}^{2}=0.69 \mathrm{vs} . \mathrm{R}^{2}=0.72\right)$. However, in daily anesthetic practice, the linear regression might be a more practical approach. Neonates and infants younger than 2 months had an enhanced CL compared to older children normalized to bodyweight, so they may require higher infusion rates.

Remifentanil is well suited for analgo-sedation during short painful procedures, but a less favorable option for postoperative pain control in non-ventilated or sedated children due to its short duration of action [161], and has gained wide acceptance [162-164]. Studies elucidating the PK-PD relationship are particularly needed in children of all age groups because of its popularity [165].

4.4.1.1 Preterm neonates: Remifentanil degradation was assessed in cord blood of preterm and term infants in vitro [166]. The in vitro half-life and degradation rate did not differ between groups without any correlation to gestational age, indicating a high non-specific esterase activity already in very preterm infants. There are no PK data reported in preterm neonates although remifentanil is increasingly used in this age group [167, 168].

4.4.1.2 Liver disease: No reported dose adjustment is necessary due to renal and hepatic impairment, but patients with severe hepatic disease may be more prone to respiratory depression $[169,170]$ 
4.4.1.3 Kidney disease: A case report of a newborn with congenital malformations and impaired renal function who received remifentanil for surgery proved a short duration of drug action [169].

4.4.1.4 Cardiopulmonary bypass: While there was no difference in $\mathrm{Vd}$ and half-life before/ after CPB, CL increased 20\% after CPB [171]. Due to low variability, plasma concentrations were well predicted even in the post-CPB phase. A study in patients who received remifentanil by computer-controlled infusion pump during open heart surgery described changes in the Vd before, during and after CPB [172].

\section{Limitations of the review}

Between all studies was large heterogeneity regarding study design, setting, drug administration and PK and PD parameters. Although most studies were prospective, nonrandomized clinical trials, a few randomized controlled and even double-blinded studies were included. Dosing schemes were variable in relation to bolus dose, short infusion or continuous infusion which may affect PK parameters, for example half-life.

Different laboratory methods for quantification of parent drug and its metabolites, for example radioimmunoassay or liquid chromatography-mass spectrometry, may account for variability in PK. Reported results were calculated or estimated using compartmental and non-compartmental PK analysis.

Effects of the previously described limitations are carried forward to linear and nonlinear regression analyses using individual patients' PK data since information on different doses, different dosing schemes, and data established by different PK parameter estimation methods were combined.

\section{Conclusions}

This review provides a comprehensive overview of the pharmacology of fentanyl and its derivatives sufentanil, alfentanil and remifentanil in the pediatric population. Despite the frequent use of these drugs in this population, there have been surprisingly few studies performed in children. There are some pediatric PK data available for all four drugs, but 800 patients are a relatively small number when compared to the extensive use of synthetic opioids in children. Most of the PK data pertains to fentanyl, which was the first synthetic opioid in its class.

Preterm and term infants showed lower clearance and protein binding for fentanyl, sufentanil and alfentanil with a large variation in drug disposition in these age groups for critical illness and/ or maturation processes. In contrast, remifentanil CL was enhanced particularly in younger children.

Clearance of fentanyl, sufentanil and alfentanil increases rapidly during the first years of life. Infants and young children even had higher CL normalized to bodyweight which might be caused by a higher metabolic capacity in these age groups or, for high-extraction ratio drugs, by increased liver blood flow. PK of fentanyl and its derivatives seemed not to be 
altered by chronic renal or hepatic disease, but sample sizes have been small and data need to be validated in larger cohorts of patients. In order to increase safety, especially studies in those age groups are needed in which the drugs are used off-label, such as remifentanil in neonates and infants younger than 1 year of age.

Fentanyl and its derivatives have proven efficacy and hemodynamic safety in children with cardiac disease who were exposed to high drug doses during cardiac surgery. Nevertheless, chest wall rigidity may occur especially in preterm and term neonates. Respiratory depression may also occur after prolonged infusion of the synthetic opioids. Routes of administration have shown to be safe and effective in children, such as transmucosal fentanyl or sufentanil delivery for premedication before surgery.

Based on the widely established use of these drugs, opportunistic clinical trials should be conducted in order to elucidate the PK and PD of fentanyl and its derivatives in much larger cohorts of the pediatric population.

\section{Acknowledgments}

Funding

The research leading to this manuscript has received funding from the European Union's Seventh Framework Programme for research; technological development and demonstration under grant agreement no. 261060 (Global Research in Paediatrics - GRiP network of excellence).

Janelle Vaughns and Johannes van den Anker were supported by an NIH Grant (5T32HD087969) to conduct this review.

\section{References}

1. Stanley TH. The history and development of the fentanyl series. J Pain Symptom Manage. 1992 Apr; 7(3 Suppl):S3-7. [PubMed: 1517629]

2. James MK, Feldman PL, Schuster SV, Bilotta JM, Brackeen MF, Leighton HJ. Opioid receptor activity of GI 87084B, a novel ultra-short acting analgesic, in isolated tissues. The Journal of pharmacology and experimental therapeutics. 1991 Nov; 259(2):712-8. [PubMed: 1658308]

3. Bovill JG, Sebel PS, Blackburn CL, Oei-Lim V, Heykants JJ. The pharmacokinetics of sufentanil in surgical patients. Anesthesiology. 1984 Nov; 61(5):502-6. [PubMed: 6238552]

4. Bower S, Hull CJ. Comparative pharmacokinetics of fentanyl and alfentanil. Br J Anaesth. 1982 Aug; 54(8):871-7. [PubMed: 6125162]

5. Feierman DE, Lasker JM. Metabolism of fentanyl, a synthetic opioid analgesic, by human liver microsomes. Role of CYP3A4. Drug Metab Dispos. 1996 Sep; 24(9):932-9. [PubMed: 8886601]

6. Tateishi T, Krivoruk Y, Ueng YF, Wood AJ, Guengerich FP, Wood M. Identification of human liver cytochrome P-450 3A4 as the enzyme responsible for fentanyl and sufentanil N-dealkylation. Anesth Analg. 1996 Jan; 82(1):167-72. [PubMed: 8712396]

7. Labroo RB, Paine MF, Thummel KE, Kharasch ED. Fentanyl metabolism by human hepatic and intestinal cytochrome P450 3A4: implications for interindividual variability in disposition, efficacy, and drug interactions. Drug Metab Dispos. 1997 Sep; 25(9):1072-80. [PubMed: 9311623]

8. Mahlke NS, Ziesenitz V, Mikus G, Skopp G. Quantitative low-volume assay for simultaneous determination of fentanyl, norfentanyl, and minor metabolites in human plasma and urine by liquid chromatography-tandem mass spectrometry (LC-MS/MS). Int J Legal Med. 2014 Sep; 128(5):7718. [PubMed: 24997532]

9. Chauvin M, Bonnet F, Montembault C, Levron JC, Viars P. The influence of hepatic plasma flow on alfentanil plasma concentration plateaus achieved with an infusion model in humans: measurement 
of alfentanil hepatic extraction coefficient. Anesth Analg. 1986 Oct; 65(10):999-1003. [PubMed: 2875679]

10. Meuldermans W, Van Peer A, Hendrickx J, Woestenborghs R, Lauwers W, Heykants J, et al. Alfentanil pharmacokinetics and metabolism in humans. Anesthesiology. 1988 Oct; 69(4):527-34. [PubMed: 3140690]

11. Murphy MR, Hug CC Jr, McClain DA. Dose-independent pharmacokinetics of fentanyl. Anesthesiology. 1983 Dec; 59(6):537-40. [PubMed: 6650910]

12. Gepts E, Shafer SL, Camu F, Stanski DR, Woestenborghs R, Van Peer A, et al. Linearity of pharmacokinetics and model estimation of sufentanil. Anesthesiology. 1995 Dec; 83(6):1194-204. [PubMed: 8533912]

13. Goresky GV, Koren G, Sabourin MA, Sale JP, Strunin L. The pharmacokinetics of alfentanil in children. Anesthesiology. 1987 Nov; 67(5):654-9. [PubMed: 3118743]

14. Westmoreland CL, Hoke JF, Sebel PS, Hug CC Jr, Muir KT. Pharmacokinetics of remifentanil (GI87084B) and its major metabolite (GI90291) in patients undergoing elective inpatient surgery. Anesthesiology. 1993 Nov; 79(5):893-903. [PubMed: 7902033]

15. Egan TD, Lemmens HJ, Fiset P, Hermann DJ, Muir KT, Stanski DR, et al. The pharmacokinetics of the new short-acting opioid remifentanil (GI87084B) in healthy adult male volunteers. Anesthesiology. 1993 Nov; 79(5):881-92. [PubMed: 7902032]

16. Hughes MA, Glass PS, Jacobs JR. Context-sensitive half-time in multicompartment pharmacokinetic models for intravenous anesthetic drugs. Anesthesiology. 1992 Mar; 76(3):33441. [PubMed: 1539843]

17. Anderson, BJ. Pharmacokinetics and Pharmacodynamics in the Pediatric Patient. In: Absalom, AR., Mason, KP., editors. Total Intravenous Anesthesia and Target Controlled Infusions. Cham; Switzerland: Springer; 2017. p. 441-516.

18. Schäfer, M. Opioide. In: Tonner, PH., Hein, L., editors. Pharmakotherapie in der Anästhesie und Intensivmedizin. Heidelberg: Springer Verlag; 2011. p. 110-8.

19. EMA. ICH topic E11 Clinical Investigation of Medicinal Products in the Paediatric Population. 2001. [cited-2016-08-18]; Available from: http://www.ema.europa.eu/docs/en_GB/ document_library/Scientific_guideline/2009/09/WC500002926.pdf

20. Goutelle S, Maurin M, Rougier F, Barbaut X, Bourguignon L, Ducher M, et al. The Hill equation: a review of its capabilities in pharmacological modelling. Fundam Clin Pharmacol. 2008 Dec; 22(6):633-48. [PubMed: 19049668]

21. Koch G, Schropp J, Jusko WJ. Assessment of non-linear combination effect terms for drug-drug interactions. J Pharmacokinet Pharmacodyn. 2016 Oct; 43(5):461-79. [PubMed: 27638639]

22. Longo, G., Montévil, M. Scaling and Scale Symmetries in Biological Systems Perspectives on Organisms Lecture Notes in Morphogenesis Berlin. Heidelberg; Germany: Springer; 2014.

23. Kuczmarski RJ, Ogden CL, Guo SS, Grummer-Strawn LM, Flegal KM, Mei Z, et al. 2000 CDC Growth Charts for the United States: methods and development. Vital and health statistics Series 11, Data from the national health survey. 2002 May.(246):1-190.

24. Johnson KL, Erickson JP, Holley FO, Scott JC. Fentanyl pharmacokinetics in the pediatric population. Anesthesiology. 1984; 61(3A):1. [PubMed: 6742467]

25. Rosaeg OP, Kitts JB, Koren G, Byford LJ. Maternal and fetal effects of intravenous patientcontrolled fentanyl analgesia during labour in a thrombocytopenic parturient. Can J Anaesth. 1992 Mar; 39(3):277-81. [PubMed: 1551160]

26. Singleton MA, Rosen JI, Fisher DM. Plasma concentrations of fentanyl in infants, children and adults. Can J Anaesth. 1987 Mar; 34(2):152-5. [PubMed: 3829301]

27. Anderson BJ, Holford NH. Tips and traps analyzing pediatric PK data. Paediatr Anaesth. 2011 Mar; 21(3):222-37. [PubMed: 21320233]

28. Grasela TH, Sheiner LB, Rambeck B, Boenigk HE, Dunlop A, Mullen PW, et al. Steady-state pharmacokinetics of phenytoin from routinely collected patient data. Clin Pharmacokinet. 1983 Jul-Aug;8(4):355-64. [PubMed: 6617043]

29. Koehntop DE, Rodman JH, Brundage DM, Hegland MG, Buckley JJ. Pharmacokinetics of fentanyl in neonates. Anesth Analg. 1986 Mar; 65(3):227-32. [PubMed: 3954090] 
30. Masey SA, Koehler RC, Ruck JR, Pepple JM, Rogers MC, Traystman RJ. Effect of abdominal distension on central and regional hemodynamics in neonatal lambs. Pediatric research. 1985 Dec; 19(12):1244-9. [PubMed: 4080441]

31. Bjorkman S, Redke F. Clearance of fentanyl, alfentanil, methohexitone, thiopentone and ketamine in relation to estimated hepatic blood flow in several animal species: application to prediction of clearance in man. The Journal of pharmacy and pharmacology. 2000 Sep; 52(9):1065-74. [PubMed: 11045886]

32. Gauntlett IS, Fisher DM, Hertzka RE, Kuhls E, Spellman MJ, Rudolph C. Pharmacokinetics of fentanyl in neonatal humans and lambs: effects of age. Anesthesiology. 1988 Nov; 69(5):683-7. [PubMed: 3189915]

33. Katz R, Kelly HW. Pharmacokinetics of continuous infusions of fentanyl in critically ill children. Crit Care Med. 1993 Jul; 21(7):995-1000. [PubMed: 8319480]

34. Ginsberg B, Howell S, Glass PS, Margolis JO, Ross AK, Dear GL, et al. Pharmacokinetic modeldriven infusion of fentanyl in children. Anesthesiology. 1996 Dec; 85(6):1268-75. [PubMed: 8968173]

35. Hertzka RE, Gauntlett IS, Fisher DM, Spellman MJ. Fentanyl-induced ventilatory depression: effects of age. Anesthesiology. 1989 Feb; 70(2):213-8. [PubMed: 2913858]

36. Olkkola KT, Hamunen K, Maunuksela EL. Clinical pharmacokinetics and pharmacodynamics of opioid analgesics in infants and children. Clin Pharmacokinet. 1995 May; 28(5):385-404. [PubMed: 7614777]

37. Van Driest SL, Marshall MD, Hachey B, Beck C, Crum K, Owen J, et al. Pragmatic pharmacology: population pharmacokinetic analysis of fentanyl using remnant samples from children after cardiac surgery. Br J Clin Pharmacol. 2016 Jun; 81(6):1165-74. [PubMed: 26861166]

38. Jacqz-Aigrain E, Burtin P. Clinical pharmacokinetics of sedatives in neonates. Clin Pharmacokinet. 1996 Dec; 31(6):423-43. [PubMed: 8968656]

39. Santeiro ML, Christie J, Stromquist C, Torres BA, Markowsky SJ. Pharmacokinetics of continuous infusion fentanyl in newborns. Journal of perinatology: official journal of the California Perinatal Association. 1997 Mar-Apr;17(2):135-9. [PubMed: 9134513]

40. Saarenmaa E, Neuvonen PJ, Fellman V. Gestational age and birth weight effects on plasma clearance of fentanyl in newborn infants. The Journal of pediatrics. $2000 \mathrm{Jun}$; 136(6):767-70. [PubMed: 10839874]

41. Collins C, Koren G, Crean P, Klein J, Roy WL, MacLeod SM. Fentanyl pharmacokinetics and hemodynamic effects in preterm infants during ligation of patent ductus arteriosus. Anesth Analg. 1985 Nov; 64(11):1078-80. [PubMed: 3840338]

42. Kearns GL, Abdel-Rahman SM, Alander SW, Blowey DL, Leeder JS, Kauffman RE. Developmental pharmacology-drug disposition, action, and therapy in infants and children. The New England journal of medicine. 2003 Sep 18; 349(12):1157-67. [PubMed: 13679531]

43. Roth B, Schlunder C, Houben F, Gunther M, Theisohn M. Analgesia and sedation in neonatal intensive care using fentanyl by continuous infusion. Dev Pharmacol Ther. 1991; 17(3-4):121-7. [PubMed: 1841826]

44. Murat I, Levron JC, Berg A, Saint-Maurice C. Effects of fentanyl on baroreceptor reflex control of heart rate in newborn infants. Anesthesiology. 1988 May; 68(5):717-22. [PubMed: 3369715]

45. Ancora G, Lago P, Garetti E, Pirelli A, Merazzi D, Mastrocola M, et al. Efficacy and safety of continuous infusion of fentanyl for pain control in preterm newborns on mechanical ventilation. The Journal of pediatrics. 2013 Sep; 163(3):645-51 e1. [PubMed: 23582138]

46. Fahnenstich H, Steffan J, Kau N, Bartmann P. Fentanyl-induced chest wall rigidity and laryngospasm in preterm and term infants. Crit Care Med. 2000 Mar; 28(3):836-9. [PubMed: 10752838]

47. Wilson AS, Stiller RL, Davis PJ, Fedel G, Chakravorti S, Israel BA, et al. Fentanyl and alfentanil plasma protein binding in preterm and term neonates. Anesth Analg. $1997 \mathrm{Feb} ; 84(2): 315-8$. [PubMed: 9024020]

48. Cartwright P, Prys-Roberts C, Gill K, Dye A, Stafford M, Gray A. Ventilatory depression related to plasma fentanyl concentrations during and after anesthesia in humans. Anesth Analg. 1983 Nov; 62(11):966-74. [PubMed: 6414339] 
49. Tran KM, Maxwell LG, Cohen DE, Adamson PC, Moll V, Kurth CD, et al. Quantification of serum fentanyl concentrations from umbilical cord blood during ex utero intrapartum therapy. Anesth Analg. 2012 Jun; 114(6):1265-7. [PubMed: 22025493]

50. Pacifici GM. Clinical pharmacology of fentanyl in preterm infants. A review. Pediatrics and neonatology. 2015 Jun; 56(3):143-8. [PubMed: 25176283]

51. Rodieux F, Wilbaux M, van den Anker JN, Pfister M. Effect of Kidney Function on Drug Kinetics and Dosing in Neonates, Infants, and Children. Clin Pharmacokinet. 2015 Dec; 54(12):1183-204. [PubMed: 26138291]

52. McClain DA, Hug CC Jr. Intravenous fentanyl kinetics. Clin Pharmacol Ther. 1980 Jul; 28(1):10614. [PubMed: 7389247]

53. Schleimer R, Benjamini E, Eisele J, Henderson G. Pharmacokinetics of fentanyl as determined by radioimmunoassay. Clin Pharmacol Ther. 1978 Feb; 23(2):188-94. [PubMed: 620479]

54. Silverstein JH, Rieders MF, McMullin M, Schulman S, Zahl K. An analysis of the duration of fentanyl and its metabolites in urine and saliva. Anesth Analg. 1993 Mar; 76(3):618-21. [PubMed: 8452277]

55. Koren G, Crean P, Goresky GV, Klein J, MacLeod SM. Pharmacokinetics of fentanyl in children with renal disease. Research communications in chemical pathology and pharmacology. 1984 Dec; 46(3):371-9. [PubMed: 6096939]

56. Koren G, Goresky G, Crean P, Klein J, MacLeod SM. Pediatric fentanyl dosing based on pharmacokinetics during cardiac surgery. Anesth Analg. 1984 Jun; 63(6):577-82. [PubMed: 6731878]

57. Buck ML. Pharmacokinetic changes during extracorporeal membrane oxygenation: implications for drug therapy of neonates. Clin Pharmacokinet. 2003; 42(5):403-17. [PubMed: 12739981]

58. Hall R. The pharmacokinetic behaviour of opioids administered during cardiac surgery. Can $\mathbf{J}$ Anaesth. 1991 Sep; 38(6):747-56. [PubMed: 1914058]

59. van den Broek MP, Groenendaal F, Egberts AC, Rademaker CM. Effects of hypothermia on pharmacokinetics and pharmacodynamics: a systematic review of preclinical and clinical studies. Clin Pharmacokinet. 2010 May; 49(5):277-94. [PubMed: 20384391]

60. Wildschut ED, Ahsman MJ, Allegaert K, Mathot RA, Tibboel D. Determinants of drug absorption in different ECMO circuits. Intensive care medicine. 2010 Dec; 36(12):2109-16. [PubMed: 20862453]

61. Hynynen M. Binding of fentanyl and alfentanil to the extracorporeal circuit. Acta anaesthesiologica Scandinavica. 1987 Nov; 31(8):706-10. [PubMed: 3124491]

62. Wildschut ED, de Wildt SN, Mathot RA, Reiss IK, Tibboel D, Van den Anker J. Effect of hypothermia and extracorporeal life support on drug disposition in neonates. Seminars in fetal \& neonatal medicine. 2013 Feb; 18(1):23-7. [PubMed: 23158109]

63. Kussman BD, Zurakowski D, Sullivan L, McGowan FX, Davis PJ, Laussen PC. Evaluation of plasma fentanyl concentrations in infants during cardiopulmonary bypass with low-volume circuits. Journal of cardiothoracic and vascular anesthesia. 2005 Jun; 19(3):316-21. [PubMed: 16130057]

64. Newland MC, Leuschen P, Sarafian LB, Hurlbert BJ, Fleming WF, Chapin JW, et al. Fentanyl intermittent bolus technique for anesthesia in infants and children undergoing cardiac surgery. $\mathrm{J}$ Cardiothorac Anesth. 1989 Aug; 3(4):407-10. [PubMed: 2520913]

65. Koren G, Barker C, Goresky G, Bohn D, Kent G, Klein J, et al. The influence of hypothermia on the disposition of fentanyl-human and animal studies. Eur J Clin Pharmacol. 1987; 32(4):373-6. [PubMed: 3609115]

66. Koren G, Crean P, Klein J, Goresky G, Villamater J, MacLeod SM. Sequestration of fentanyl by the cardiopulmonary bypass (CPBP). Eur J Clin Pharmacol. 1984; 27(1):51-6. [PubMed: 6489427]

67. Koren G, Goresky G, Crean P, Klein J, MacLeod SM. Unexpected alterations in fentanyl pharmacokinetics in children undergoing cardiac surgery: age related or disease related? Dev Pharmacol Ther. 1986; 9(3):183-91. [PubMed: 3709338]

68. Hodges UM, Berg S, Naik SK, Bower S, Lloyd-Thomas A, Elliot M. Filtration of fentanyl is not the cause of the elevation of arterial blood pressure associated with post-bypass ultrafiltration in 
children. Journal of cardiothoracic and vascular anesthesia. 1994 Dec; 8(6):653-7. [PubMed: 7880994]

69. Taenzer AH, Groom R, Quinn RD. Fentanyl plasma levels after modified ultrafiltration in infant heart surgery. The Journal of extra-corporeal technology. 2005 Dec; 37(4):369-72. [PubMed: 16524154]

70. Crean P, Koren G, Goresky G, Klein J, Macleod S. Fentanyl-oxygen versus fentanyl-N2O/oxygen anaesthesia in children undergoing cardiac surgery. Canadian Anaesthetists' Society journal. 1986 Jan; 33(1):36-40. [PubMed: 3948045]

71. Gruber EM, Laussen PC, Casta A, Zimmerman AA, Zurakowski D, Reid R, et al. Stress response in infants undergoing cardiac surgery: a randomized study of fentanyl bolus, fentanyl infusion, and fentanyl-midazolam infusion. Anesth Analg. 2001 Apr; 92(4):882-90. [PubMed: 11273919]

72. Kussman BD, Gruber EM, Zurakowski D, Hansen DD, Sullivan LJ, Laussen PC. Bispectral index monitoring during infant cardiac surgery: relationship of BIS to the stress response and plasma fentanyl levels. Paediatr Anaesth. 2001 Nov; 11(6):663-9. [PubMed: 11696141]

73. Arnold JH, Truog RD, Scavone JM, Fenton T. Changes in the pharmacodynamic response to fentanyl in neonates during continuous infusion. The Journal of pediatrics. 1991 Oct; 119(4):63943. [PubMed: 1919898]

74. Arnold JH, Truog RD, Orav EJ, Scavone JM, Hershenson MB. Tolerance and dependence in neonates sedated with fentanyl during extracorporeal membrane oxygenation. Anesthesiology. 1990 Dec; 73(6):1136-40. [PubMed: 2248393]

75. Leuschen MP, Willett LD, Hoie EB, Bolam DL, Bussey ME, Goodrich PD, et al. Plasma fentanyl levels in infants undergoing extracorporeal membrane oxygenation. The Journal of thoracic and cardiovascular surgery. 1993 May; 105(5):885-91. [PubMed: 8487566]

76. Vaughns JD, Ziesenitz VC, van den Anker JN. Clinical Pharmacology of Frequently Used Intravenous Drugs During Bariatric Surgery in Adolescents. Curr Pharm Des. 2015; 21(39):5650 9. [PubMed: 26323414]

77. Smith HL, Meldrum DJ, Brennan LJ. Childhood obesity: a challenge for the anaesthetist? Paediatr Anaesth. 2002 Nov; 12(9):750-61. [PubMed: 12519133]

78. Barlow SE, Expert C. Expert committee recommendations regarding the prevention, assessment, and treatment of child and adolescent overweight and obesity: summary report. Pediatrics. 2007 Dec; 120(Suppl 4):S164-92. [PubMed: 18055651]

79. Vaughns JD, Ziesenitz VC, Williams EF, Mushtaq A, Bachmann R, Skopp G, et al. Use of Fentanyl in Adolescents with Clinically Severe Obesity Undergoing Bariatric Surgery: A Pilot Study. Paediatric drugs. 2017 Feb 25.

80. Adams JP, Murphy PG. Obesity in anaesthesia and intensive care. Br J Anaesth. 2000 Jul; 85(1): 91-108. [PubMed: 10927998]

81. Mulla H, Johnson TN. Dosing dilemmas in obese children. Archives of disease in childhood Education and practice edition. 2010 Aug; 95(4):112-7. [PubMed: 20585055]

82. Schumann R. Anaesthesia for bariatric surgery. Best Pract Res Clin Anaesthesiol. 2011 Mar; 25(1): 83-93. [PubMed: 21516916]

83. Shibutani K, Inchiosa MA Jr, Sawada K, Bairamian M. Accuracy of pharmacokinetic models for predicting plasma fentanyl concentrations in lean and obese surgical patients: derivation of dosing weight ("pharmacokinetic mass"). Anesthesiology. 2004 Sep; 101(3):603-13. [PubMed: 15329584]

84. Shibutani K, Inchiosa MA Jr, Sawada K, Bairamian M. Pharmacokinetic mass of fentanyl for postoperative analgesia in lean and obese patients. Br J Anaesth. 2005 Sep; 95(3):377-83. [PubMed: 16024584]

85. Ingrande J, Lemmens HJ. Dose adjustment of anaesthetics in the morbidly obese. Br J Anaesth. 2010 Dec; 105(Suppl 1):i16-23. [PubMed: 21148651]

86. Leykin Y, Miotto L, Pellis T. Pharmacokinetic considerations in the obese. Best Pract Res Clin Anaesthesiol. 2011 Mar; 25(1):27-36. [PubMed: 21516911]

87. Lejus C, Schwoerer D, Furic I, Le Moing JP, Levron JC, Pinaud M. Fentanyl versus sufentanil: plasma concentrations during continuous epidural postoperative infusion in children. Br J Anaesth. 2000 Oct; 85(4):615-7. [PubMed: 11064622] 
88. Karas-Trzeciak M, Grabowski T, Woloszczuk-Gebicka B, Borucka B. Fentanyl with ropivacaine infusion for postoperative pain relief in infants and children. Kinetics of epidural fentanyl. Paediatr Anaesth. 2015 Aug; 25(8):818-23. [PubMed: 25904383]

89. Preston RA, Csontos ER, East KA, Kessler KF, Fisk SP, Streisand JB. Plasma fentanyl concentrations after oral transmucosal fentanyl citrate: children versus adults. Anesthesiology. 1993; 79:1. [PubMed: 8342796]

90. Dsida RM, Wheeler M, Birmingham PK, Henthorn TK, Avram MJ, Enders-Klein C, et al. Premedication of pediatric tonsillectomy patients with oral transmucosal fentanyl citrate. Anesth Analg. 1998 Jan; 86(1):66-70. [PubMed: 9428853]

91. Lotsch J, Walter C, Parnham MJ, Oertel BG, Geisslinger G. Pharmacokinetics of non-intravenous formulations of fentanyl. Clin Pharmacokinet. 2013 Jan; 52(1):23-36. [PubMed: 23100195]

92. Wheeler M, Birmingham PK, Dsida RM, Wang Z, Cote CJ, Avram MJ. Uptake pharmacokinetics of the Fentanyl Oralet in children scheduled for central venous access removal: implications for the timing of initiating painful procedures. Paediatr Anaesth. 2002 Sep; 12(7):594-9. [PubMed: 12358654]

93. Wheeler M, Birmingham PK, Lugo RA, Heffner CL, Cote CJ. The pharmacokinetics of the intravenous formulation of fentanyl citrate administered orally in children undergoing general anesthesia. Anesth Analg. 2004 Nov; 99(5):1347-51. table of contents. [PubMed: 15502029]

94. Epstein RH, Mendel HG, Witkowski TA, Waters R, Guarniari KM, Marr AT, et al. The safety and efficacy of oral transmucosal fentanyl citrate for preoperative sedation in young children. Anesth Analg. 1996 Dec; 83(6):1200-5. [PubMed: 8942586]

95. Streisand JB, Stanley TH, Hague B, van Vreeswijk H, Ho GH, Pace NL. Oral transmucosal fentanyl citrate premedication in children. Anesth Analg. 1989 Jul; 69(1):28-34. [PubMed: 2742165]

96. Friesen RH, Carpenter E, Madigan CK, Lockhart CH. Oral transmucosal fentanyl citrate for preanaesthetic medication of paediatric cardiac surgery patients. Paediatr Anaesth. 1995; 5(1):2933. [PubMed: 8521306]

97. Schechter NL, Weisman SJ, Rosenblum M, Bernstein B, Conard PL. The use of oral transmucosal fentanyl citrate for painful procedures in children. Pediatrics. 1995 Mar; 95(3):335-9. [PubMed: 7862469]

98. Borland ML, Bergesio R, Pascoe EM, Turner S, Woodger S. Intranasal fentanyl is an equivalent analgesic to oral morphine in paediatric burns patients for dressing changes: a randomised double blind crossover study. Burns. 2005 Nov; 31(7):831-7. [PubMed: 16005154]

99. Borland M, Jacobs I, King B, O’Brien D. A randomized controlled trial comparing intranasal fentanyl to intravenous morphine for managing acute pain in children in the emergency department. Ann Emerg Med. 2007 Mar; 49(3):335-40. [PubMed: 17067720]

100. Finn M, Harris D. Intranasal fentanyl for analgesia in the paediatric emergency department. Emergency medicine journal: EMJ. 2010 Apr; 27(4):300-1. [PubMed: 20385685]

101. Harlos MS, Stenekes S, Lambert D, Hohl C, Chochinov HM. Intranasal fentanyl in the palliative care of newborns and infants. J Pain Symptom Manage. 2013 Aug; 46(2):265-74. [PubMed: 23017621]

102. Mudd S. Intranasal fentanyl for pain management in children: a systematic review of the literature. J Pediatr Health Care. 2011 Sep-Oct;25(5):316-22. [PubMed: 21867860]

103. Paut O, Camboulives J, Viard L, Lemoing JP, Levron JC. Pharmacokinetics of transdermal fentanyl in the peri-operative period in young children. Anaesthesia. $2000 \mathrm{Dec} ; 55(12): 1202-7$. [PubMed: 11121932]

104. Collins JJ, Dunkel IJ, Gupta SK, Inturrisi CE, Lapin J, Palmer LN, et al. Transdermal fentanyl in children with cancer pain: feasibility, tolerability, and pharmacokinetic correlates. J Pediatr. 1999 Mar; 134(3):319-23. [PubMed: 10064669]

105. Lehmann KA, Zech D. Transdermal fentanyl: clinical pharmacology. J Pain Symptom Manage. 1992 Apr; 7(3 Suppl):S8-16. [PubMed: 1517637]

106. Delgado-Charro MB, Guy RH. Effective use of transdermal drug delivery in children. Adv Drug Deliv Rev. 2014 Jun.73:63-82. [PubMed: 24333231] 
107. Zernikow B, Michel E, Anderson B. Transdermal fentanyl in childhood and adolescence: a comprehensive literature review. J Pain. 2007 Mar; 8(3):187-207. [PubMed: 17350554]

108. Greeley WJ, de Bruijn NP, Davis DP. Sufentanil pharmacokinetics in pediatric cardiovascular patients. Anesth Analg. 1987 Nov; 66(11):1067-72. [PubMed: 2959170]

109. Greeley WJ, de Bruijn NP. Changes in sufentanil pharmacokinetics within the neonatal period. Anesth Analg. 1988 Jan; 67(1):86-90. [PubMed: 2892438]

110. Guay J, Gaudreault P, Tang A, Goulet B, Varin F. Pharmacokinetics of sufentanil in normal children. Can J Anaesth. 1992 Jan; 39(1):14-20. [PubMed: 1531117]

111. Meistelman C, Benhamou D, Barre J, Levron JC, Mahe V, Mazoit X, et al. Effects of age on plasma protein binding of sufentanil. Anesthesiology. 1990 Mar; 72(3):470-3. [PubMed: 2137997]

112. Meuldermans WE, Hurkmans RM, Heykants JJ. Plasma protein binding and distribution of fentanyl, sufentanil, alfentanil and lofentanil in blood. Archives internationales de pharmacodynamie et de therapie. 1982 May; 257(1):4-19. [PubMed: 6214227]

113. Meuldermans W, Woestenborghs R, Noorduin H, Camu F, van Steenberge A, Heykants J. Protein binding of the analgesics alfentanil and sufentanil in maternal and neonatal plasma. Eur J Clin Pharmacol. 1986; 30(2):217-9. [PubMed: 2940093]

114. Helmers JH, van Leeuwen L, Zuurmond WW. Sufentanil pharmacokinetics in young adult and elderly surgical patients. Eur J Anaesthesiol. 1994 May; 11(3):181-5. [PubMed: 8050423]

115. Scholz J, Bause H, Schulz M, Klotz U, Krishna DR, Pohl S, et al. Pharmacokinetics and effects on intracranial pressure of sufentanil in head trauma patients. Br J Clin Pharmacol. 1994 Oct; 38(4):369-72. [PubMed: 7833228]

116. Bartkowska-Sniatkowska A, Bienert A, Wiczling P, Rosada-Kurasinska J, Zielinska M, Warzybok $\mathrm{J}$, et al. Pharmacokinetics of sufentanil during long-term infusion in critically ill pediatric patients. Journal of clinical pharmacology. 2016 Jan; 56(1):109-15. [PubMed: 26105145]

117. Calvier EA, Krekels EH, Valitalo PA, Rostami-Hodjegan A, Tibboel D, Danhof M, et al. Allometric Scaling of Clearance in Paediatric Patients: When Does the Magic of 0.75 Fade? Clin Pharmacokinet. 2017 Mar; 56(3):273-85. [PubMed: 27510367]

118. Nguyen The Tich S. Vecchierini MF, Debillon T, Pereon Y. Effects of sufentanil on electroencephalogram in very and extremely preterm neonates. Pediatrics. 2003 Jan; 111(1):1238. [PubMed: 12509564]

119. Davis PJ, Stiller RL, Cook DR, Brandom BW, Davin-Robinson KA. Pharmacokinetics of sufentanil in adolescent patients with chronic renal failure. Anesth Analg. 1988 Mar; 67(3):26871. [PubMed: 2964213]

120. Davis PJ, Cook DR, Stiller RL, Davin-Robinson KA. Pharmacodynamics and pharmacokinetics of high-dose sufentanil in infants and children undergoing cardiac surgery. Anesth Analg. 1987 Mar; 66(3):203-8. [PubMed: 2950809]

121. Kern FH, Ungerleider RM, Jacobs JR, Boyd JL 3rd, Reves JG, Goodman D, et al. Computerized continuous infusion of intravenous anesthetic drugs during pediatric cardiac surgery. Anesth Analg. 1991 Apr; 72(4):487-92. [PubMed: 1826072]

122. Woloszczuk-Gebicka B, Grabowski T, Borucka B, Karas-Trzeciak M. Pharmacokinetics of sufentanil administered with $0.2 \%$ ropivacaine as a continuous epidural infusion for postoperative pain relief in infants. Paediatr Anaesth. 2014 Sep; 24(9):962-7. [PubMed: 24824135]

123. Benlabed M, Ecoffey C, Levron JC, Flaisler B, Gross JB. Analgesia and ventilatory response to CO2 following epidural sufentanil in children. Anesthesiology. 1987 Dec; 67(6):948-51. [PubMed: 2891331]

124. Henderson JM, Brodsky DA, Fisher DM, Brett CM, Hertzka RE. Pre-induction of anesthesia in pediatric patients with nasally administered sufentanil. Anesthesiology. 1988 May; 68(5):671-5. [PubMed: 2897172]

125. Lundeberg S, Roelofse JA. Aspects of pharmacokinetics and pharmacodynamics of sufentanil in pediatric practice. Paediatr Anaesth. 2011 Mar; 21(3):274-9. [PubMed: 20849451]

126. Karl HW, Keifer AT, Rosenberger JL, Larach MG, Ruffle JM. Comparison of the safety and efficacy of intranasal midazolam or sufentanil for preinduction of anesthesia in pediatric patients. Anesthesiology. 1992 Feb; 76(2):209-15. [PubMed: 1531286] 
127. Abrams R, Morrison JE, Villasenor A, Hencmann D, Da Fonseca M, Mueller W. Safety and effectiveness of intranasal administration of sedative medications (ketamine, midazolam, or sufentanil) for urgent brief pediatric dental procedures. Anesth Prog. 1993; 40(3):63-6. [PubMed: 7645790]

128. Zedie N, Amory DW, Wagner BK, O’Hara DA. Comparison of intranasal midazolam and sufentanil premedication in pediatric outpatients. Clin Pharmacol Ther. 1996 Mar; 59(3):341-8. [PubMed: 8653997]

129. Haynes G, Brahen NH, Hill HF. Plasma sufentanil concentration after intranasal administration to paediatric outpatients. Can J Anaesth. 1993 Mar.40(3):286. [PubMed: 8467552]

130. Nielsen BN, Friis SM, Romsing J, Schmiegelow K, Anderson BJ, Ferreiros N, et al. Intranasal sufentanil/ketamine analgesia in children. Paediatr Anaesth. 2014 Feb; 24(2):170-80. [PubMed: 24118506]

131. Meistelman C, Saint-Maurice C, Lepaul M, Levron JC, Loose JP, Mac Gee K. A comparison of alfentanil pharmacokinetics in children and adults. Anesthesiology. 1987 Jan; 66(1):13-6. [PubMed: 3099603]

132. Roure P, Jean N, Leclerc AC, Cabanel N, Levron JC, Duvaldestin P. Pharmacokinetics of alfentanil in children undergoing surgery. Br J Anaesth. 1987 Nov; 59(11):1437-40. [PubMed: 3120765]

133. Browne BL, Prys-Roberts C, Wolf AR. Propofol and alfentanil in children: infusion technique and dose requirement for total i.v. anaesthesia. Br J Anaesth. 1992 Dec; 69(6):570-6. [PubMed: 1467099]

134. Wiest DB, Ohning BL, Garner SS. The disposition of alfentanil in neonates with respiratory distress. Pharmacotherapy. 1991; 11(4):308-11. [PubMed: 1923912]

135. Davis PJ, Killian A, Stiller RL, Cook DR, Guthrie RD, Scierka AM. Pharmacokinetics of alfentanil in newborn premature infants and older children. Dev Pharmacol Ther. 1989; 13(1):217. [PubMed: 2505988]

136. Freid EB, Miles MV, Nocera MA, Zaritsky AL. Prolonged Continuous Infusions of Fentanyl or Alfentanil in Critically Ill Children - Pharmacokinetics and Pharmacodynamics. Anesthesiology. 1994 Sep; 81(3A):A257-A.

137. Davis PJ, Stiller RL, Cook DR, Brandom BW, Davis JE, Scierka AM. Effects of cholestatic hepatic disease and chronic renal failure on alfentanil pharmacokinetics in children. Anesth Analg. 1989 May; 68(5):579-83. [PubMed: 2497657]

138. Bjorkman S. Prediction of cytochrome p450-mediated hepatic drug clearance in neonates, infants and children: how accurate are available scaling methods? Clin Pharmacokinet. 2006; 45(1):111. [PubMed: 16430308]

139. Edginton AN, Schmitt W, Willmann S. Development and evaluation of a generic physiologically based pharmacokinetic model for children. Clin Pharmacokinet. 2006; 45(10):1013-34. [PubMed: 16984214]

140. Salem F, Johnson TN, Abduljalil K, Tucker GT, Rostami-Hodjegan A. A reevaluation and validation of ontogeny functions for cytochrome P450 1A2 and 3A4 based on in vivo data. Clin Pharmacokinet. 2014 Jul; 53(7):625-36. [PubMed: 24671884]

141. Johnson TN, Rostami-Hodjegan A, Tucker GT. Prediction of the clearance of eleven drugs and associated variability in neonates, infants and children. Clin Pharmacokinet. 2006; 45(9):931-56. [PubMed: 16928154]

142. Marlow N, Weindling AM, Van Peer A, Heykants J. Alfentanil pharmacokinetics in preterm infants. Archives of disease in childhood. 1990 Apr.65:349-51. 4 Spec No. [PubMed: 2337359]

143. Killian A, Davis PJ, Stiller RL, Cicco R, Cook DR, Guthrie RD. Influence of gestational age on pharmacokinetics of alfentanil in neonates. Dev Pharmacol Ther. 1990; 15(2):82-5. [PubMed: 2078976]

144. Pokela ML, Ryhanen PT, Koivisto ME, Olkkola KT, Saukkonen AL. Alfentanil-induced rigidity in newborn infants. Anesth Analg. 1992 Aug; 75(2):252-7. [PubMed: 1632539]

145. Rodighiero V. Effects of liver disease on pharmacokinetics. An update. Clin Pharmacokinet. 1999 Nov; 37(5):399-431. [PubMed: 10589374] 
146. Tegeder I, Lotsch J, Geisslinger G. Pharmacokinetics of opioids in liver disease. Clin Pharmacokinet. 1999 Jul; 37(1):17-40. [PubMed: 10451781]

147. Ferrier C, Marty J, Bouffard Y, Haberer JP, Levron JC, Duvaldestin P. Alfentanil pharmacokinetics in patients with cirrhosis. Anesthesiology. 1985 Apr; 62(4):480-4. [PubMed: 3920934]

148. den Hollander JM, Hennis PJ, Burm AG, Vletter AA, Bovill JG. Pharmacokinetics of alfentanil before and after cardiopulmonary bypass in pediatric patients undergoing cardiac surgery: Part I. Journal of cardiothoracic and vascular anesthesia. 1992 Jun; 6(3):308-12. [PubMed: 1610996]

149. den Hollander JM, Hennis PJ, Burm AG, Bovill JG. Alfentanil in infants and children with congenital heart defects. J Cardiothorac Anesth. 1988 Feb; 2(1):12-7. [PubMed: 2979128]

150. Ross AK, Davis PJ, Dear Gd GL, Ginsberg B, McGowan FX, Stiller RD, et al. Pharmacokinetics of remifentanil in anesthetized pediatric patients undergoing elective surgery or diagnostic procedures. Anesth Analg. 2001 Dec; 93(6):1393-401. table of contents. [PubMed: 11726413]

151. Staschen CM, Mahmood I. A population pharmacokinetic model of remifentanil in pediatric patients using body-weight-dependent allometric exponents. Drug Metabol Drug Interact. 2013; 28(4):231-7. [PubMed: 24114900]

152. Rigby-Jones AE, Priston MJ, Sneyd JR, McCabe AP, Davis GI, Tooley MA, et al. Remifentanilmidazolam sedation for paediatric patients receiving mechanical ventilation after cardiac surgery. Br J Anaesth. 2007 Aug; 99(2):252-61. [PubMed: 17578905]

153. Standing JF, Hammer GB, Sam WJ, Drover DR. Pharmacokinetic-pharmacodynamic modeling of the hypotensive effect of remifentanil in infants undergoing cranioplasty. Paediatr Anaesth. 2010 Jan; 20(1):7-18. [PubMed: 19825011]

154. Galinkin JL, Davis PJ, McGowan FX, Lynn AM, Rabb MF, Yaster M, et al. A randomized multicenter study of remifentanil compared with halothane in neonates and infants undergoing pyloromyotomy. II. Perioperative breathing patterns in neonates and infants with pyloric stenosis. Anesth Analg. 2001 Dec; 93(6):1387-92. table of contents. [PubMed: 11726412]

155. Welzing L, Roth B. Experience with remifentanil in neonates and infants. Drugs. 2006; 66(10): 1339-50. [PubMed: 16903768]

156. Allegaert $\mathrm{K}$. The clinical pharmacology of short acting analgo-sedatives in neonates. Current clinical pharmacology. 2011 Nov; 6(4):222-6. [PubMed: 22082329]

157. Stoppa F, Perrotta D, Tomasello C, Cecchetti C, Marano M, Pasotti E, et al. Low dose remifentanyl infusion for analgesia and sedation in ventilated newborns. Minerva anestesiologica. 2004 Nov; 70(11):753-61. [PubMed: 15699911]

158. Kamata M, Tobias JD. Remifentanil: applications in neonates. Journal of anesthesia. 2016 Jun; 30(3):449-60. [PubMed: 26758072]

159. Barker N, Lim J, Amari E, Malherbe S, Ansermino JM. Relationship between age and spontaneous ventilation during intravenous anesthesia in children. Paediatr Anaesth. 2007 Oct; 17(10):948-55. [PubMed: 17767630]

160. Davis PJ, Galinkin J, McGowan FX, Lynn AM, Yaster M, Rabb MF, et al. A randomized multicenter study of remifentanil compared with halothane in neonates and infants undergoing pyloromyotomy. I. Emergence and recovery profiles. Anesth Analg. 2001 Dec; 93(6):1380-6. table of contents. [PubMed: 11726411]

161. Allegaert K, Thewissen L, van den Anker JN. Remifentanil in neonates: a promising compound in search of its indications? Pediatrics and neonatology. 2012 Dec; 53(6):387-8. [PubMed: 23276446]

162. Davis PJ, Cladis FP. The use of ultra-short-acting opioids in paediatric anaesthesia: the role of remifentanil. Clin Pharmacokinet. 2005; 44(8):787-96. [PubMed: 16029065]

163. Marsh DF, Hodkinson B. Remifentanil in paediatric anaesthetic practice. Anaesthesia. 2009 Mar; 64(3):301-8. [PubMed: 19302645]

164. Sammartino M, Garra R, Sbaraglia F, De Riso M, Continolo N. Remifentanil in children. Paediatr Anaesth. 2010 Mar; 20(3):246-55. [PubMed: 20102527]

165. Rothstein P. Remifentanil for neonates and infants: piano, piano con calma. Anesth Analg. 2001 Dec; 93(6):1370-2. [PubMed: 11726408] 
166. Welzing L, Ebenfeld S, Dlugay V, Wiesen MH, Roth B, Mueller C. Remifentanil degradation in umbilical cord blood of preterm infants. Anesthesiology. 2011 Mar; 114(3):570-7. [PubMed: 21258236]

167. Norman E, Wikstrom S, Hellstrom-Westas L, Turpeinen U, Hamalainen E, Fellman V. Rapid sequence induction is superior to morphine for intubation of preterm infants: a randomized controlled trial. The Journal of pediatrics. 2011 Dec; 159(6):893-9 e1. [PubMed: 21798556]

168. Sammartino M, Garra R, Sbaraglia F, De Riso M, Continolo N, Papacci P. Experience of remifentanil in extremely low-birth-weight babies undergoing laparotomy. Pediatrics and neonatology. 2011 Jun; 52(3):176-9. [PubMed: 21703563]

169. Eck JB, Lynn AM. Use of remifentanil in infants. Paediatr Anaesth. 1998; 8(5):437-9. [PubMed: 9742543]

170. Dershwitz M, Hoke JF, Rosow CE, Michalowski P, Connors PM, Muir KT, et al. Pharmacokinetics and pharmacodynamics of remifentanil in volunteer subjects with severe liver disease. Anesthesiology. 1996 Apr; 84(4):812-20. [PubMed: 8638835]

171. Davis PJ, Wilson AS, Siewers RD, Pigula FA, Landsman IS. The effects of cardiopulmonary bypass on remifentanil kinetics in children undergoing atrial septal defect repair. Anesth Analg. 1999 Oct; 89(4):904-8. [PubMed: 10512263]

172. Sam WJ, Hammer GB, Drover DR. Population pharmacokinetics of remifentanil in infants and children undergoing cardiac surgery. BMC Anesthesiol. 2009; 9:5. [PubMed: 19635151]

173. Freye, E. Pharmakokinetik der Opioide: Bedeutung für den praktischen Einsatz. In: Freye, E., editor. Opioide in der Medizin. 6. Berlin Heidelberg: Springer-Verlag; 2004. p. 229-35.

174. Freye, E. Opioide im Rahmen der Allgemeinanästhesie. In: Freye, E., editor. Opioide in der Medizin. 6. Berlin Heidelberg: Springer-Verlag; 2004. p. 193-228.

175. Kretz, F-J., Schäffer, J., Gleiter, CH., Krebsbach, W., Hindley, U., Remppis, S. Pharmakologie Grundlagen und klinisch-praktische Details. In: Kretz, F-J.Schäffer, J.Gleiter, CH.Krebsbach, W.Hindley, U., Remppis, S., editors. Anästhesie Intensivmedizin Notfallmedizin Schmerztherapie. 5. Heidelberg: Springer Verlag; 2008. p. 18

176. Peng PW, Sandler AN. A review of the use of fentanyl analgesia in the management of acute pain in adults. Anesthesiology. 1999 Feb; 90(2):576-99. [PubMed: 9952166]

177. Schäfer, M. Opioide. In: Tonner, PH., Hein, L., editors. Pharmakotherapie in der Anästhesie und Intensivmedizin. 1. Heidelberg: Springer Verlag; 2011. p. 109-30.

178. Schäfer, M., Zöllner, C. Opioide. In: Rossaint, R.Werner, C., Zwissler, B., editors. Die Anästhesiologie - Allgemeine und spezielle Anästhesiologie, Schmerztherapie und Intensivmedizin. 3. Berlin Heidelberg: Springer-Verlag; 2012. p. 240

179. Scholz J, Steinfath M, Schulz M. Clinical pharmacokinetics of alfentanil, fentanyl and sufentanil. An update. Clin Pharmacokinet. 1996 Oct; 31(4):275-92. [PubMed: 8896944]

180. Bovill JG, Sebel PS, Blackburn CL, Heykants J. The pharmacokinetics of alfentanil (R39209): a new opioid analgesic. Anesthesiology. 1982 Dec; 57(6):439-43. [PubMed: 6128948]

181. Gillespie TJ, Gandolfi AJ, Maiorino RM, Vaughan RW. Gas chromatographic determination of fentanyl and its analogues in human plasma. J Anal Toxicol. 1981 May-Jun;5(3):133-7. [PubMed: 6115094]

182. Michiels M, Hendriks R, Heykants J. A sensitive radioimmunoassay for fentanyl. Plasma level in dogs and man. Eur J Clin Pharmacol. 1977 Oct 14; 12(2):153-8. [PubMed: 923629]

183. Schuttler J, White PF. Optimization of the radioimmunoassays for measuring fentanyl and alfentanil in human serum. Anesthesiology. 1984 Sep; 61(3):315-20. [PubMed: 6433750]

184. Watts V, Caplan Y. Determination of fentanyl in whole blood at subnanogram concentrations by dual capillary column gas chromatography with nitrogen sensitive detectors and gas chromatography/mass spectrometry. J Anal Toxicol. 1988 Sep-Oct;12(5):246-54. [PubMed: 2906381]

185. Woestenborghs RJ, Stanski DR, Scott JC, Heykants JJ. Assay methods for fentanyl in serum: gasliquid chromatography versus radioimmunoassay. Anesthesiology. 1987 Jul; 67(1):85-90. [PubMed: 3605738] 
186. Koch DE, Isaza R, Carpenter JW, Hunter RP. Simultaneous extraction and quantitation of fentanyl and norfentanyl from primate plasma with LC/MS detection. J Pharm Biomed Anal. 2004 Feb 18; 34(3):577-84. [PubMed: 15127814]

187. Liu J, Pan H, Gold MS, Derendorf H, Bruijnzeel AW. Effects of fentanyl dose and exposure duration on the affective and somatic signs of fentanyl withdrawal in rats. Neuropharmacology. 2008 Oct; 55(5):812-8. [PubMed: 18634811]

188. Michiels M, Hendriks R, Heykants J. Radioimmunoassay of the new opiate analgesics alfentanil and sufentanil. Preliminary pharmacokinetic profile in man. The Journal of pharmacy and pharmacology. 1983 Feb; 35(2):86-93. [PubMed: 6131992]

189. Heykants J, Woestenborghs R, Timmerman P. Reliability of sufentanil plasma level assays in patients. Anesthesiology. 1986 Jul; 65(1):112-3. [PubMed: 2942060]

190. Fiset P, Mathers L, Engstrom R, Fitzgerald D, Brand SC, Hsu F, et al. Pharmacokinetics of computer-controlled alfentanil administration in children undergoing cardiac surgery. Anesthesiology. 1995 Nov; 83(5):944-55. [PubMed: 7486179]

191. Hynynen M, Takkunen O, Salmenpera M, Haataja H, Heinonen J. Continuous infusion of fentanyl or alfentanil for coronary artery surgery. Plasma opiate concentrations, haemodynamics and postoperative course. Br J Anaesth. 1986 Nov; 58(11):1252-9. [PubMed: 3096364]

192. Grosse CM, Davis IM, Arrendale RF, Jersey J, Amin J. Determination of remifentanil in human blood by liquid-liquid extraction and capillary GC-HRMS-SIM using a deuterated internal standard. J Pharm Biomed Anal. 1994 Feb; 12(2):195-203. [PubMed: 8003546]

193. Lessard D, Comeau B, Charlebois A, Letarte L, Davis IM. Quantification of GR90291 in human blood by high resolution gas chromatography-mass selective detection (HRGC-MSD). J Pharm Biomed Anal. 1994 May; 12(5):659-65. [PubMed: 7948187] 


\section{Key Points}

- $\quad$ Fentanyl and its derivatives have been approved long ago, but there is still a lack of knowledge regarding pharmacokinetics in children.

- In the future, opportunistic clinical trials should be performed the PK and PD of fentanyl and its derivatives in much larger cohorts of the pediatric population, also in order to have more dosing evidence in subpopulations, such as obese children, and children with liver or kidney impairment. 


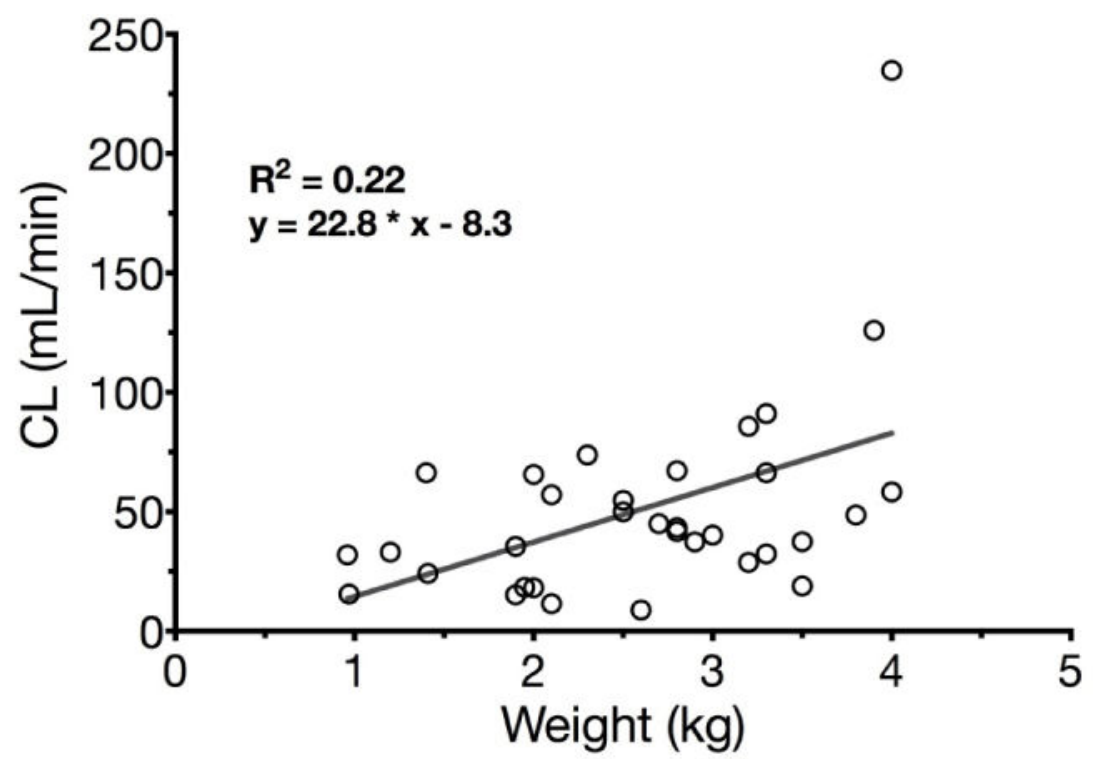

Fig. 1.

Linear regression of fentanyl clearance and bodyweight in preterm and term neonates $\left(\mathrm{R}^{2}=0.22\right.$, solid grey line $)$. 


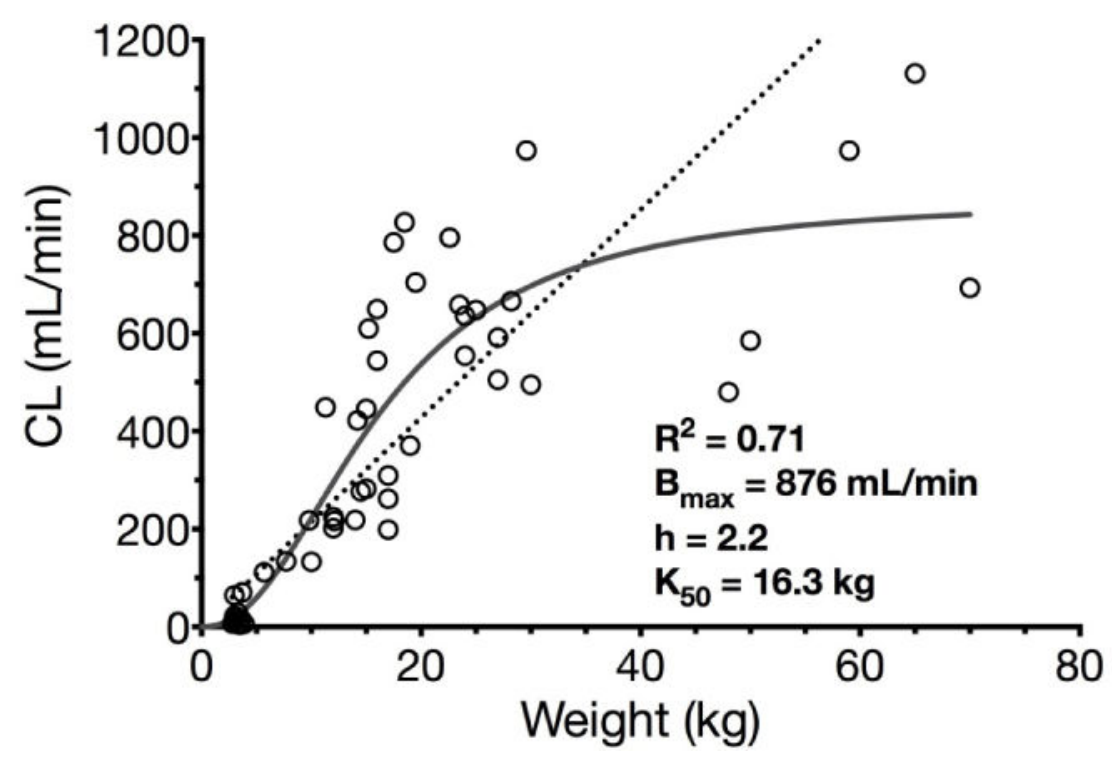

Fig. 2.

Nonlinear regression (Hill function) of sufentanil clearance and bodyweight in children including term neonates $\left(\mathrm{R}^{2}=0.71\right.$, solid grey line $)$. Allometric function of sufentanil clearance and bodyweight in children including term neonates $\left(\mathrm{R}^{2}=0.67\right.$, dotted black line $)$. Abbreviations: $B_{\max }$ maximum clearance, $K_{50}$ bodyweight at which half-maximum clearance is reached, $h$ Hill coefficient. 


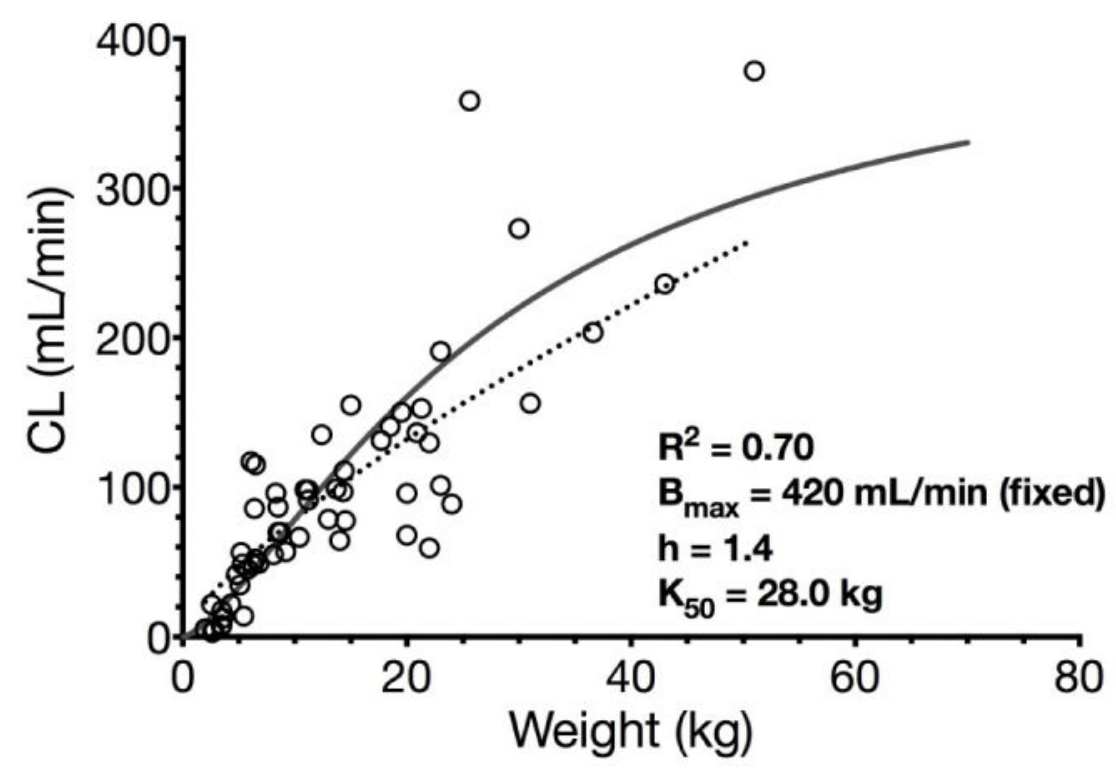

Fig. 3.

Nonlinear regression (Hill function) of alfentanil clearance and bodyweight in children including preterm and term neonates $\left(\mathrm{R}^{2}=0.70\right.$, solid grey line). Allometric function of alfentanil clearance and bodyweight in children including preterm and term neonates ( $\mathrm{R}^{2}=0.65$, dotted black line). Abbreviations: $B_{\max }$ maximum clearance, $K_{50}$ bodyweight at which half-maximum clearance is reached, $h$ Hill coefficient. 


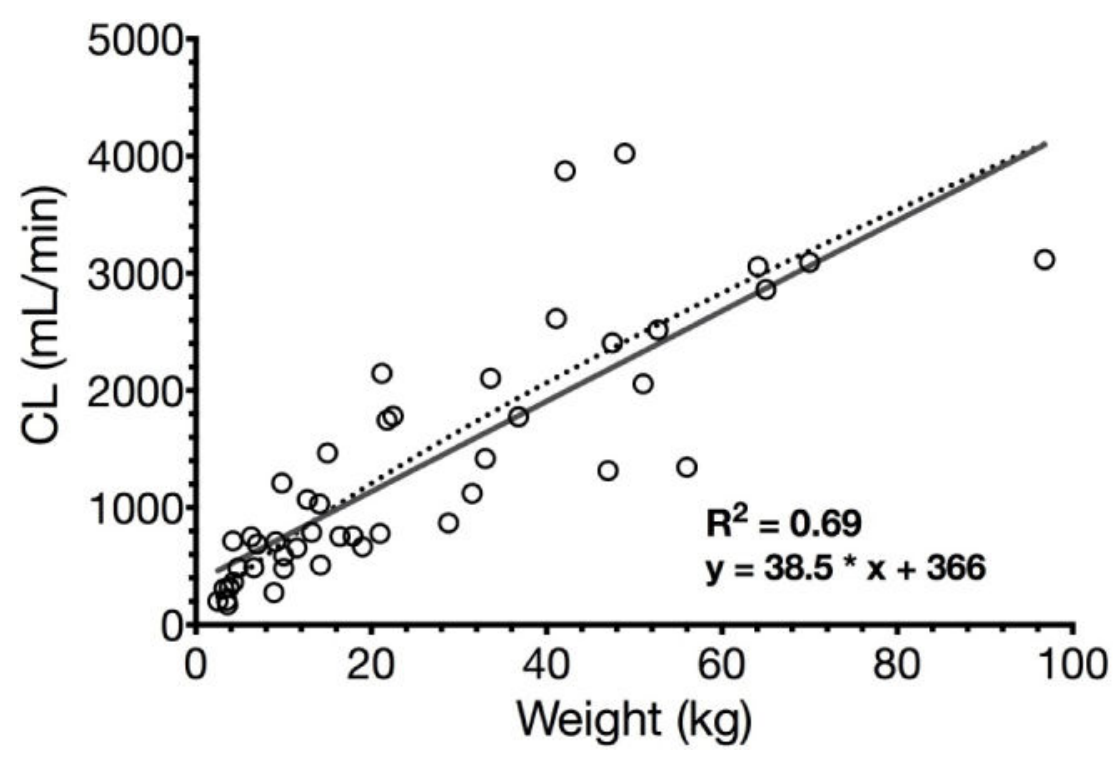

Fig. 4.

Linear regression of remifentanyl clearance and bodyweight in children including neonates $\left(\mathrm{R}^{2}=0.69\right.$, solid grey line). Allometric function of remifentanil clearance and bodyweight in children neonates $\left(\mathrm{R}^{2}=0.72\right.$, dotted black line $)$. 
Table 1

Overview of pharmacological properties of fentanyl and its derivatives $[3,4,14,15,52,112,173-180]$.

\begin{tabular}{|c|c|c|c|c|}
\hline & Fentanyl & Sufentanil & Alfentanil & Remifentanil \\
\hline Potency compared to morphine & $100-300$ & $800-1000$ & $40-50$ & $100-200$ \\
\hline IV induction dose $(\mu \mathrm{g} / \mathrm{kg})$ & $2-6$ & $0.25-2.0$ & $25-100$ & $1-2$ \\
\hline IV maintenance dose $(\mu \mathrm{g} / \mathrm{kg})$ & $0.5-2$ & $2.5-10$ & $5-10$ & $0.1-1.0$ \\
\hline IV infusion rate $(\mu \mathrm{g} / \mathrm{kg} / \mathrm{h})$ & $0.5-5$ & $0.5-1.5$ & $30-120$ & $0.1-1.0$ \\
\hline $\begin{array}{l}\text { Other routes of administration than } \\
\text { IV }\end{array}$ & $\begin{array}{c}\text { transdermal, } \\
\text { transmucosal } \\
\text { (buccal, nasal, } \\
\text { sublingual), epidural }\end{array}$ & epidural, sublingual & & \\
\hline Time to onset (min) & 1.5 & 1 & 0.75 & $<1$ \\
\hline Time to peak effect (min) & $4.5-8$ & $2.5-5$ & 1.5 & 1.5 \\
\hline Duration of peak effect (min) & $20-30$ & 30 & 15 & \\
\hline Duration of analgesic effect (min) & $60-120$ & $100-150$ & $30-60$ & $5-10$ \\
\hline $\begin{array}{l}\text { Analgesic plasma concentration } \\
(\mathrm{ng} / \mathrm{mL})\end{array}$ & $0.6-3.0$ & $0.5-2.5$ & $50-300$ & $0.3-3$ \\
\hline $\begin{array}{l}\text { Plasma concentration associated with } \\
\text { loss of consciousness }(\mathrm{ng} / \mathrm{mL})\end{array}$ & $>20.0$ & $>2.5$ & $>400$ & $>4$ \\
\hline $\mathbf{t}_{1 / 2 a}(\min )$ & $1.7 \pm 0.1$ & $1.4 \pm 0.3$ & $1.31 \pm 0.48$ & 1 \\
\hline $\mathbf{t}_{1 / 2 \beta}(\min )$ & $13.4 \pm 1.6$ & $17.7 \pm 2.6$ & $9.4 \pm 2.7$ & 6 \\
\hline $\mathbf{t}_{1 / 2 \gamma}(\min )$ & $\begin{array}{l}219 \pm 10 \\
(120-240)\end{array}$ & $\begin{array}{l}164 \pm 22 \\
(120-180)\end{array}$ & $\begin{array}{r}93.7 \pm 8.3 \\
(60-120)\end{array}$ & $\begin{array}{l}10-20 \\
(6-14)\end{array}$ \\
\hline $\mathbf{V d} \mathbf{d}_{\mathrm{c}}(\mathbf{L} / \mathbf{k g})$ & $0.36 \pm 0.07$ & $0.16 \pm 0.02$ & $0.12 \pm 0.04$ & 0.1 \\
\hline$V d_{s s}(L / k g)$ & $\begin{array}{l}4.0 \pm 0.4 \\
(3-5)\end{array}$ & $\begin{array}{l}1.7 \pm 0.2 \\
(2.5-3.0)\end{array}$ & $\begin{array}{l}1.0 \pm 0.3 \\
(0.4-1.0)\end{array}$ & $\begin{array}{c}0.35 \\
(0.2-0.4)\end{array}$ \\
\hline $\mathrm{CL}(\mathrm{mL} / \mathrm{min} / \mathrm{kg})$ & $\begin{array}{l}13 \pm 2 \\
(10-20)\end{array}$ & $\begin{array}{l}12.7 \pm 0.8 \\
(10-15)\end{array}$ & $\begin{array}{l}7.6 \pm 2.4 \\
(3-9)\end{array}$ & $\begin{array}{c}40 \\
(30-60)\end{array}$ \\
\hline Protein binding (\%) & $80-84$ & $91-92.5$ & $88.7-92.1$ & 70 \\
\hline pKa & 8.4 & 8.0 & 6.5 & 7.1 \\
\hline Non-ionized fraction @ pH $7.40(\%)$ & 8.5 & 20 & 89 & 67 \\
\hline Metabolism & CYP3A & CYP3A & CYP3A & $\begin{array}{l}\text { Plasma and tissue } \\
\text { esterases }\end{array}$ \\
\hline $\begin{array}{l}\text { Lipid solubility (octanol/water } \\
\text { distribution coefficient) }\end{array}$ & $813-816$ & $1727-1778$ & 128 & 18 \\
\hline References & $\begin{array}{c}{[14,52,112,173-} \\
179]\end{array}$ & $\begin{array}{c}{[3,14,112,173-175,177-} \\
179]\end{array}$ & $\begin{array}{c}{[4,14,112,173-} \\
175,177-180]\end{array}$ & $\begin{array}{c}{[14,15,112,173-} \\
175,177-179]\end{array}$ \\
\hline
\end{tabular}

Abbreviations: $\mathrm{t}_{1 / 2} a$ distribution half-life, $\mathrm{t}_{1 / 2} \beta$ redistribution half-life, $\mathrm{t}_{1 / 2} \gamma$ terminal elimination half-life, $\mathrm{Vd}_{\mathrm{C}}$ volume of distribution of the central compartment, $\mathrm{Vd}_{\mathrm{SS}}$ volume of distribution at steady state, $\mathrm{CL}$ clearance.

Italic numbers indicate information from the Summary of Product Characteristics (SPC). 


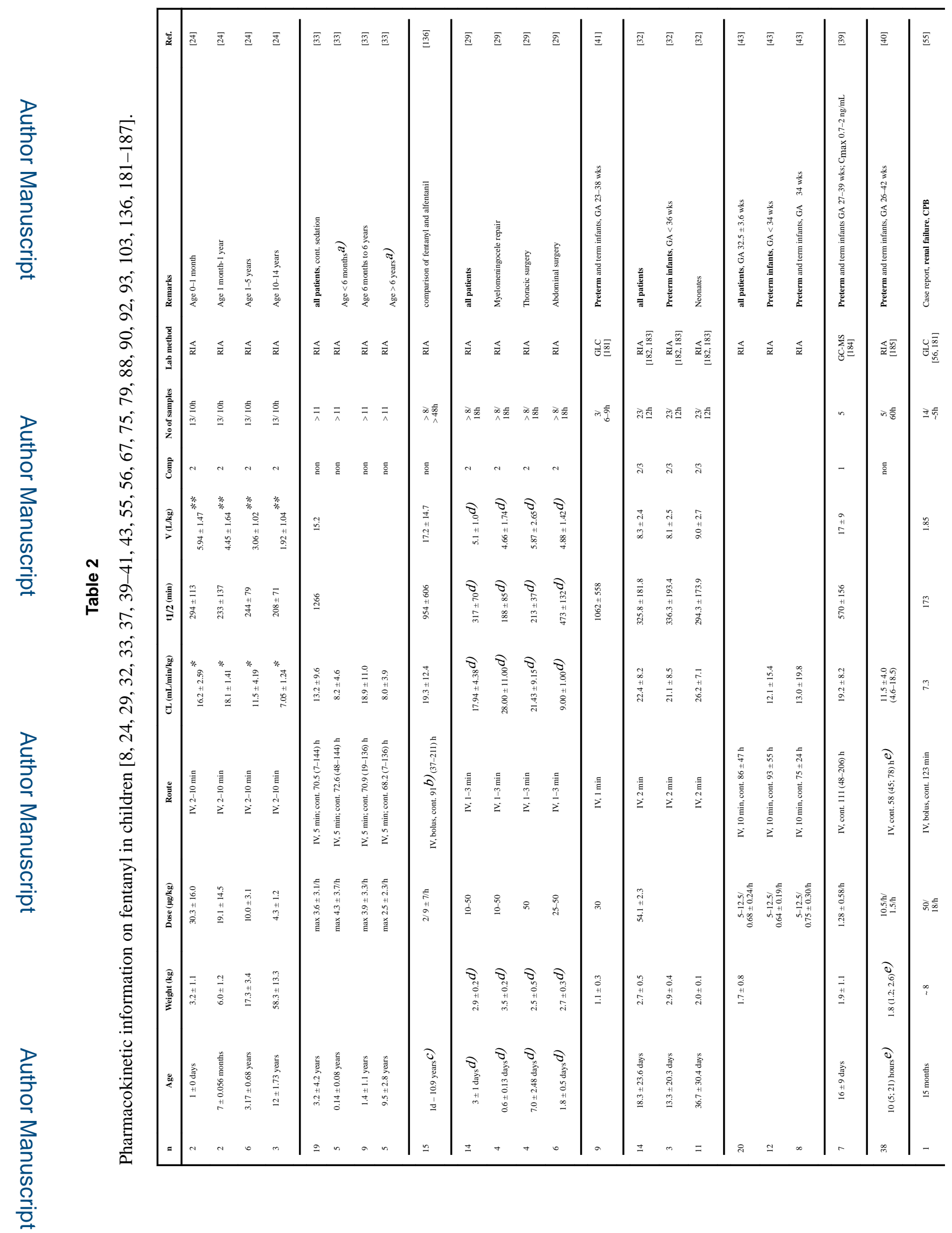

Clin Pharmacokinet. Author manuscript; available in PMC 2019 February 01. 


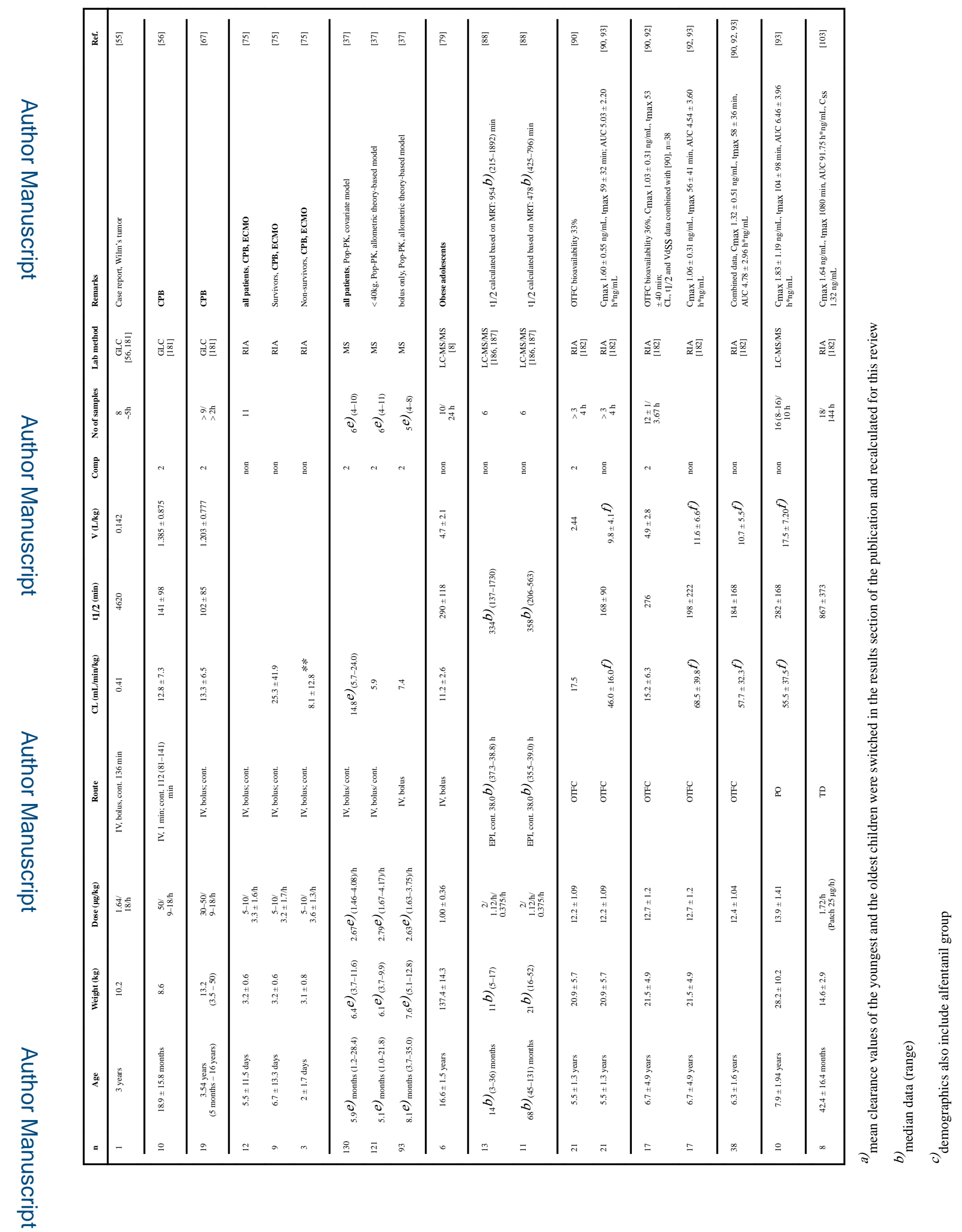

Clin Pharmacokinet. Author manuscript; available in PMC 2019 February 01. 

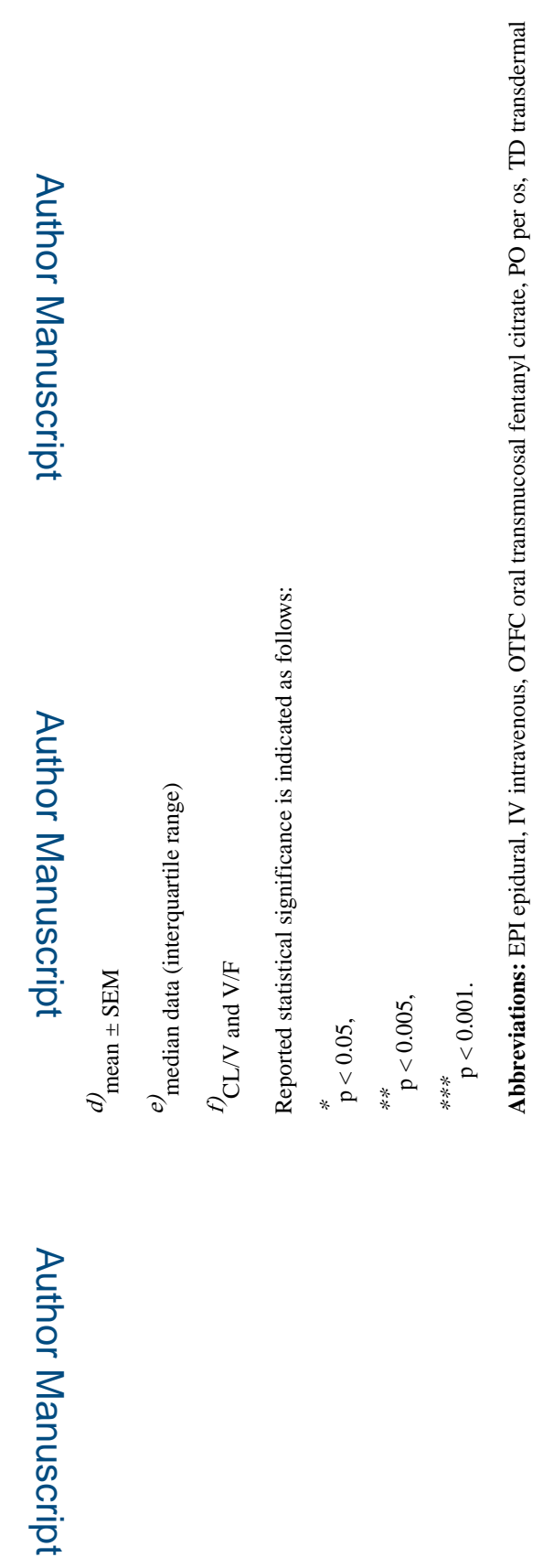

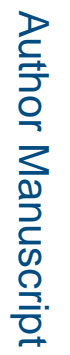

Clin Pharmacokinet. Author manuscript; available in PMC 2019 February 01. 


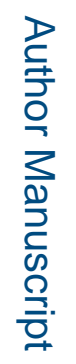

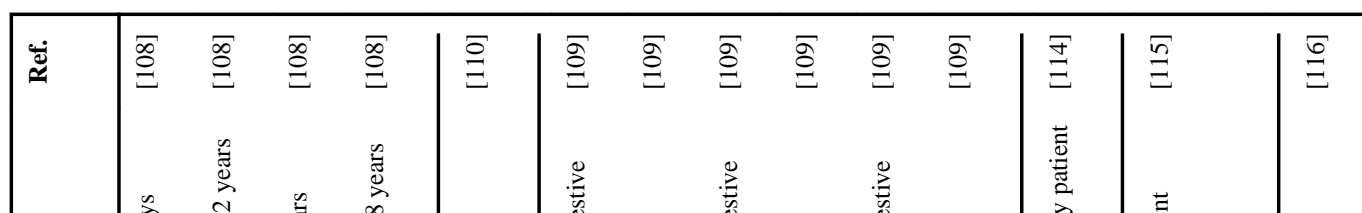

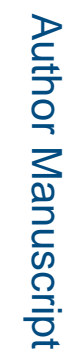

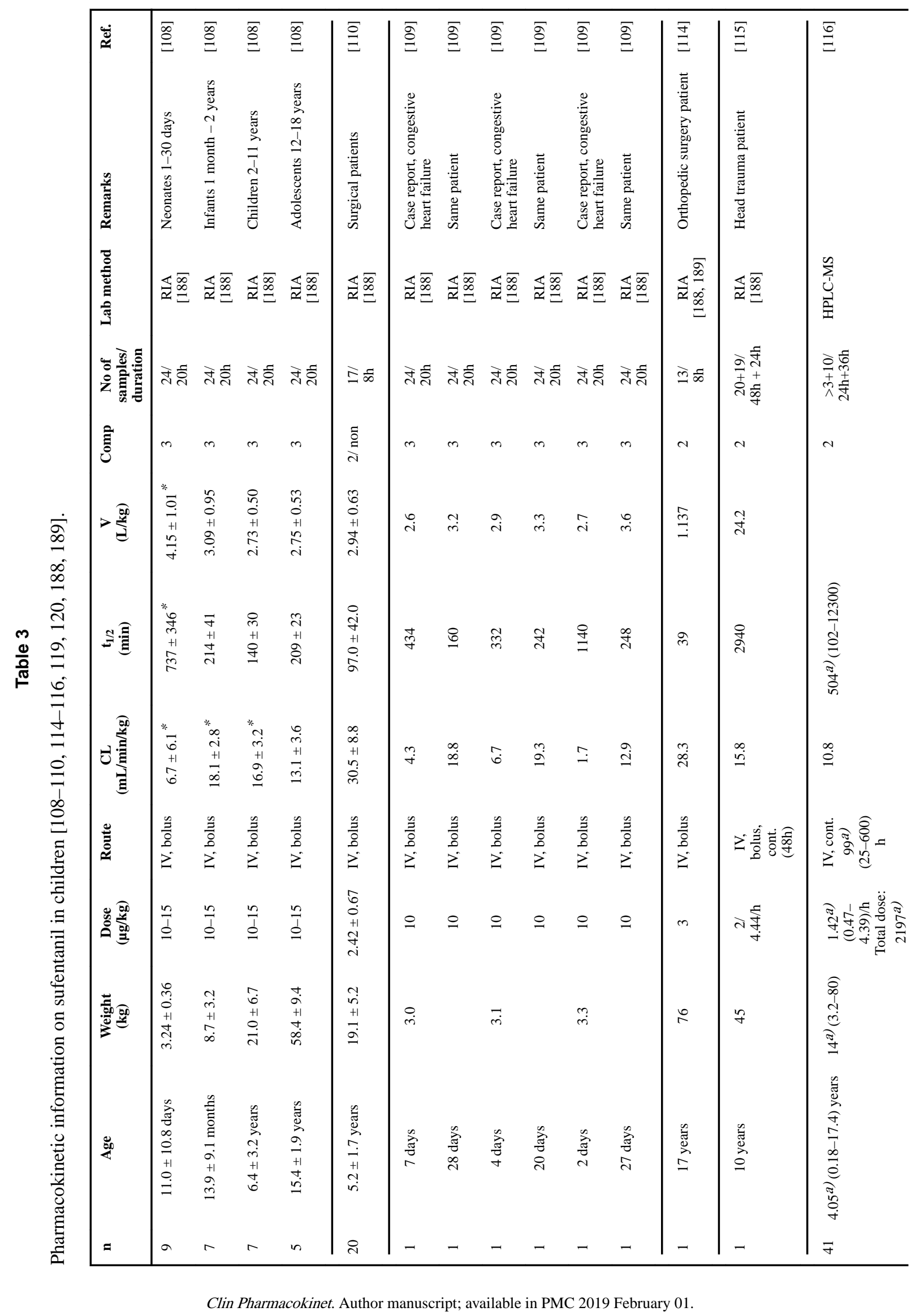




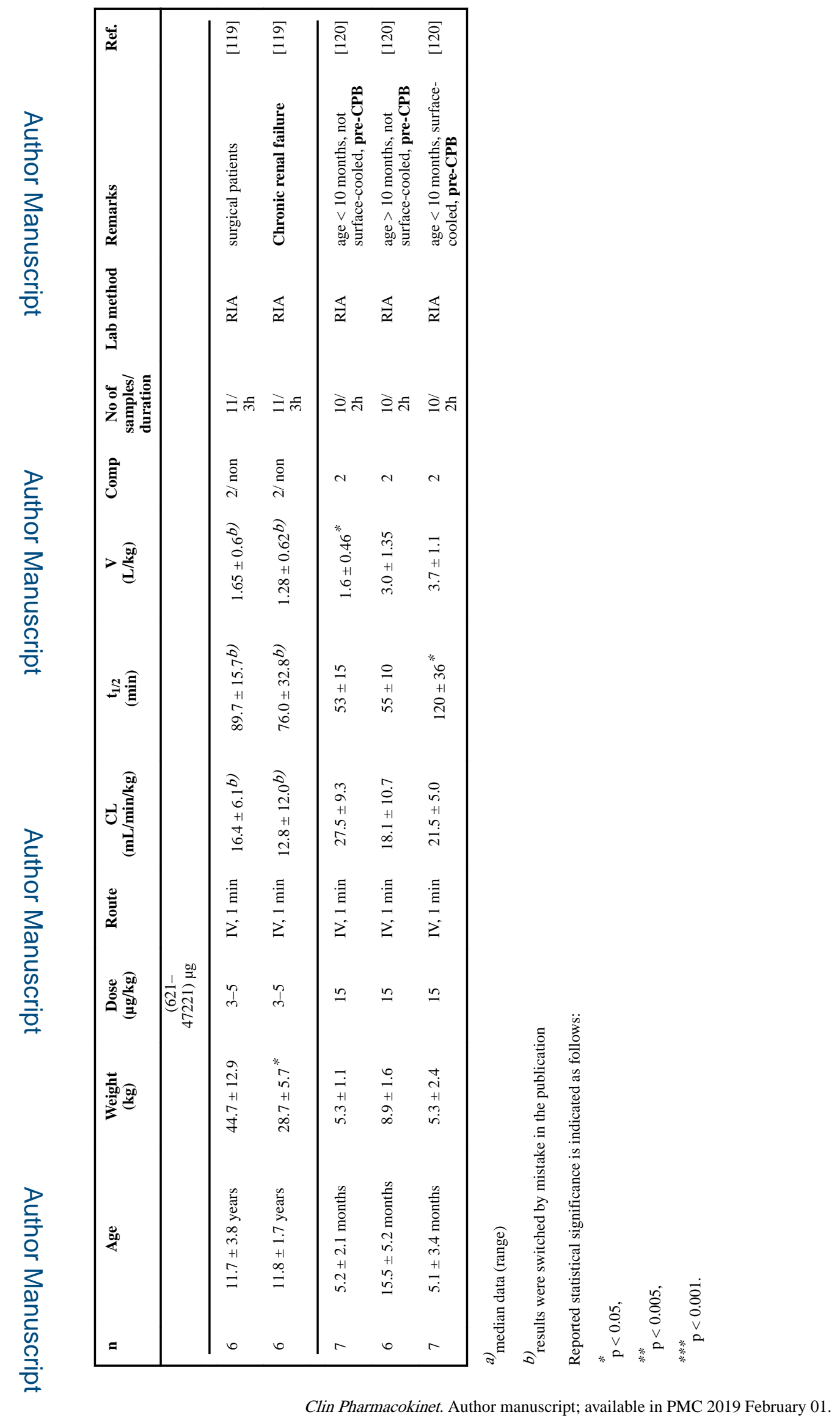




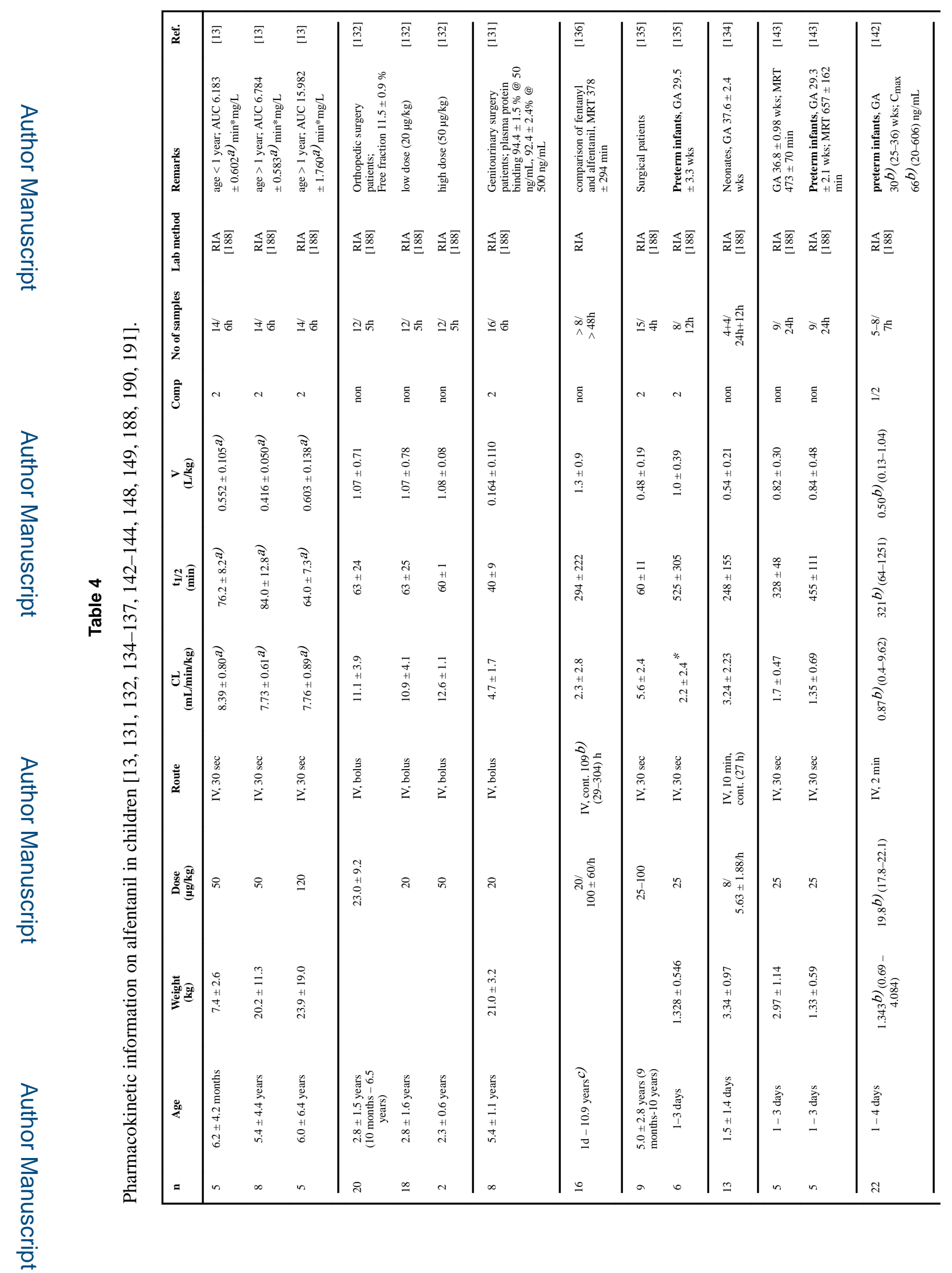

Clin Pharmacokinet. Author manuscript; available in PMC 2019 February 01. 


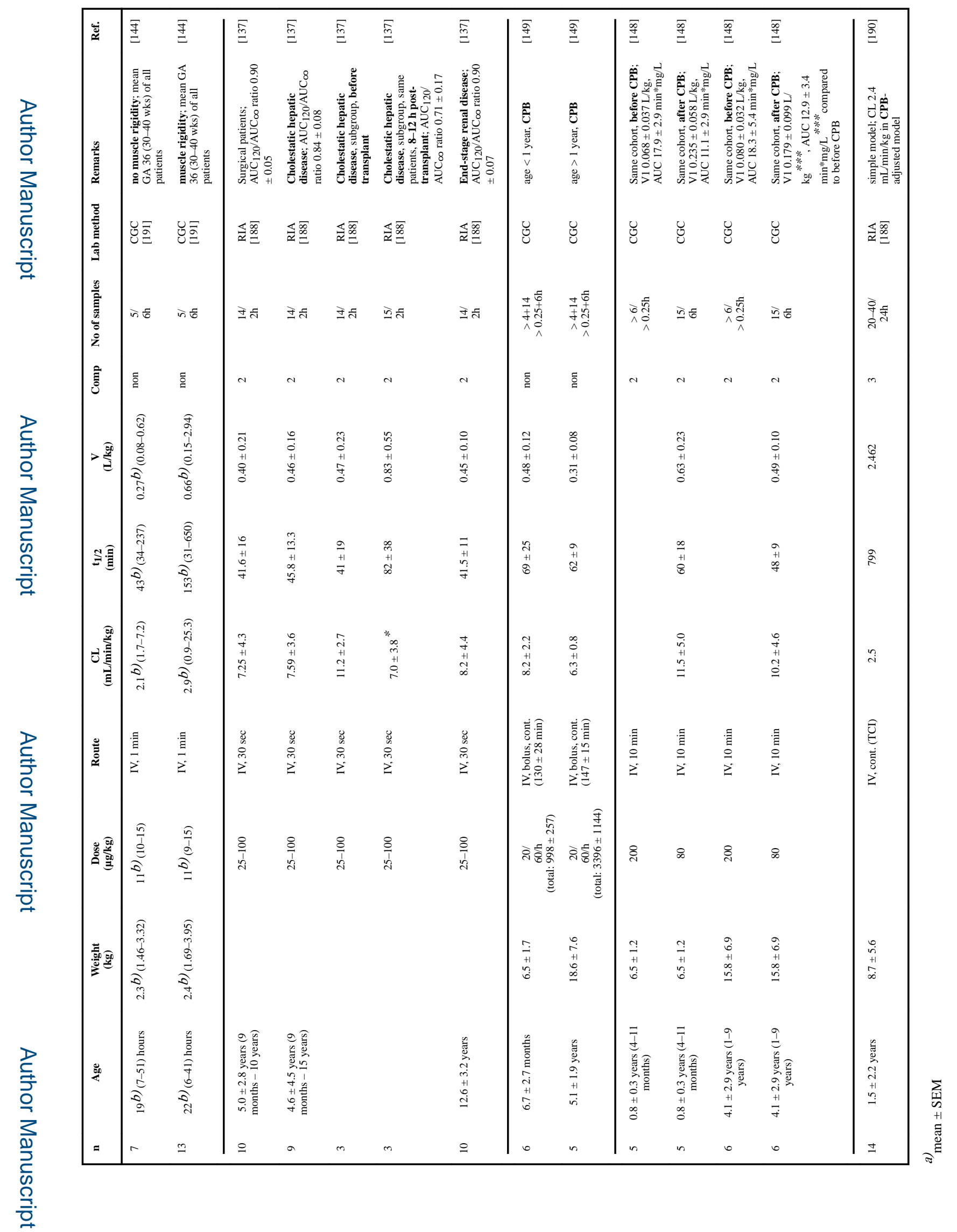

Clin Pharmacokinet. Author manuscript; available in PMC 2019 February 01. 

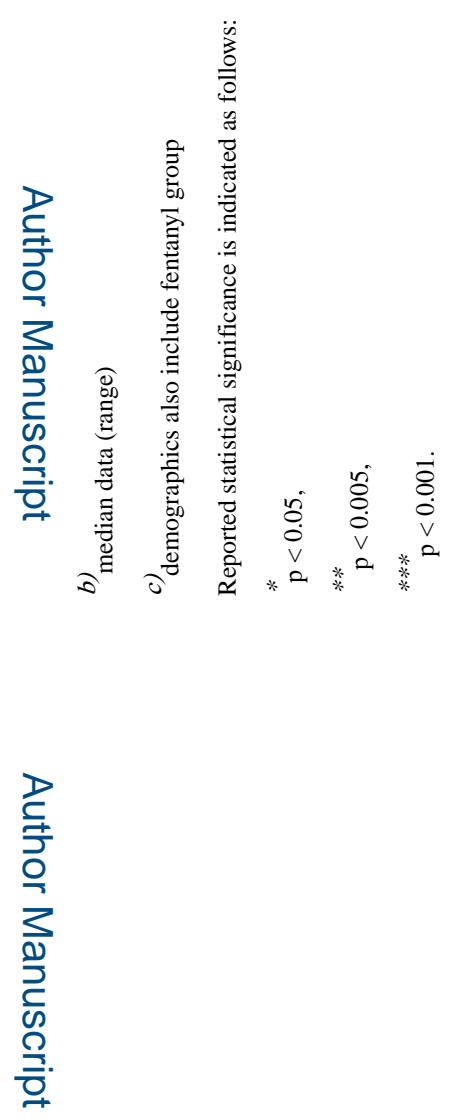

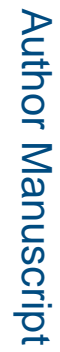

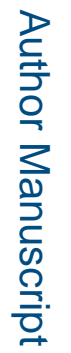

Clin Pharmacokinet. Author manuscript; available in PMC 2019 February 01. 


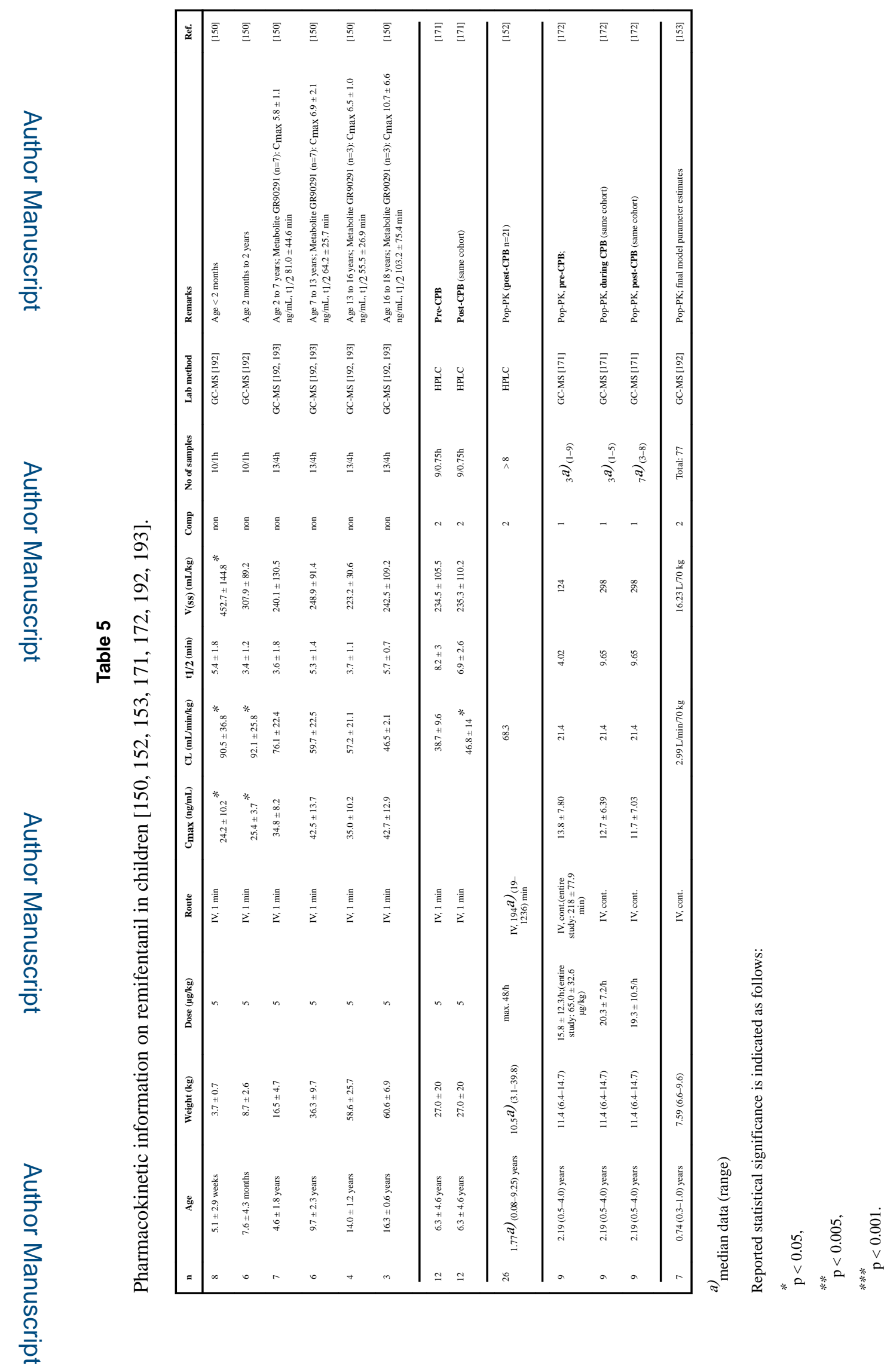

Clin Pharmacokinet. Author manuscript; available in PMC 2019 February 01. 